\title{
Fluid flow and metasomatic fault weakening in the Moresby Seamount detachment, Woodlark Basin, offshore Papua New Guinea
}

\author{
Romed Speckbacher and Jan H. Behrmann \\ GEOMAR, Helmboltz Centre for Ocean Research Kiel, DE-24148 Kiel, Germany \\ (rspeckbacher@geomar.de) \\ Thorsten J. Nagel \\ Steinmann-Institute, University of Bonn, DE-53115 Bonn, Germany \\ Michael Stipp and Julia Mahlke \\ GEOMAR, Helmboltz Centre for Ocean Research Kiel, DE-24148 Kiel, Germany
}

[1] Low-angle normal faults play a prominent role in discussions about fault strength, as they require significant weakening to remain active at low angles. The submerged Moresby Seamount detachment (MSD) is arguably the best exposed active low-angle detachment worldwide. We analyzed dredged MSD protoliths, cataclasites and mylonites to investigate deformation mechanisms and fault-weakening processes. Deformation is accompanied by important syntectonic, fluid-induced mass transfer, controlling the rheological behavior of the MSD. While the mafic protolith behaves brittlely at the onset of deformation, the metasomatic mineralogical and chemical changes cause a transition to plastic flow as the rock is progressively exhumed. Immobile elements provide a reference frame for total material gains and losses. $\mathrm{Si}, \mathrm{Ca}$ and $\mathrm{K}$ are syntectonically enriched, while $\mathrm{Fe}, \mathrm{Ti}, \mathrm{Mg}$, and $\mathrm{Al}$ are depleted. Mass increase is about $10 \%$ in the cataclasites and about $48 \%$ in the mylonites. Main mechanism is syntectonic veining, causing enrichment in calcite and quartz, thus making the mylonites capable to flow plastically. Minimum timeintegrated fluid flux is calculated as $3 \times 10^{5} \mathrm{~m}^{3} \mathrm{~m}^{-2}$, indicating that the MSD is an important fluid conduit. The fluids have a deep crustal source, a bottom water temperature and turbidity anomaly suggests that the hydrothermal system is still active. Syntectonic veining in fault rocks and recent seismic activity both suggest that the MSD is intermittently brittle, implying a brittle-plastic transition at unusually high temperature and low differential stress. We conclude that fault zone metasomatism is crucial in forming weak detachments at passive margins, and may be a prerequisite for successful crustal breakup.

Components: 14,800 words, 13 figures, 2 tables.

Keywords: Woodlark Basin; detachment fault; fault weakening; fluid flow; mass transfer; rifting.

Index Terms: 8105 Tectonophysics: Continental margins: divergent (1212, 8124); 8118 Tectonophysics: Dynamics and mechanics of faulting (8004).

Received 27 August 2012; Revised 27 September 2012; Accepted 27 September 2012; Published 30 November 2012.

Speckbacher, R., J. H. Behrmann, T. J. Nagel, M. Stipp, and J. Mahlke (2012), Fluid flow and metasomatic fault weakening in the Moresby Seamount detachment, Woodlark Basin, offshore Papua New Guinea, Geochem. Geophys. Geosyst., 13, Q11016, doi:10.1029/2012GC004407. 


\section{Introduction}

[2] Faults as strain localizing zones are by definition weaker than the non-faulted surrounding rocks. The question "How weak"? has motivated innumerable studies over decades of years [e.g., Scholz, 1998; Axen, 1999; Zoback, 2000]. While most experimental studies support the notion of relatively strong fault zones [e.g., Byerlee, 1978], many field observations indicate low fault strength [e.g., Zoback, 2000; Gueydan et al., 2003]. Low-angle detachment faults [Axen, 2004; Collettini, 2011] are particularly important in the discussions of fault strength, as these require operation at low differential stress and resolved shear stress. Low-angle detachments are documented in much of the geologic record [e.g., Froitzheim and Eberli, 1990; Holm and Lux, 1996; Axen, 1999], in extensional and compressive continental tectonic settings [e.g., Behrmann, 1988; Burchfiel et al., 1992], and at slow-spreading mid-ocean ridges [e.g., Tucholke et al., 1998]. However, more than two decades of debate have not led to a consensus about how initial weakening and sustained operation of detachment faults occurs. To date almost all studies focusing on the petrographic record of weakening processes are on exposed fossil continental examples, but in recent years new insights have arisen from studying detachments at mid-ocean ridges and offshore rifting scenarios [e.g., Smith et al., 2006; Garcés and Gee, 2007; Tani et al., 2011; Speckbacher et al., 2011], where tectonic structures and evolution is young or still active (thus simpler).

[3] The lateral variation from active continental rifting to seafloor spreading makes the western Woodlark Basin (Figure 1) one of the best studied regions to examine the process of lithospheric extension [e.g., Weissel et al., 1982; Mutter et al., 1996; Abers et al., 1997; Goodliffe et al., 1997; Taylor et al., 1995, 1999; Goodliffe and Taylor, 2007]. The Moresby Seamount detachment (MSD) offshore Papua New Guinea (Figures 2 and 3) is a prime example of a low-angle detachment fault [Taylor et al., 1999; Axen, 2004; Speckbacher et al., 2011] as it represents one of the very few places on Earth where seismically active low-angle normal faulting has been identified [Abers et al., 1997].

[4] In the Woodlark Basin abundant effusive magmatism and extensional faulting occur simultaneously, suggesting very low faulting stress levels. Slip on the MSD requires either low apparent fault friction relative to laboratory values [e.g., Marone and Cox, 1994], or rotation of the stress field around the fault. There is little support for the latter hypothesis [Reynolds and Lister, 1987; Axen and Selverstone, 1994], as near-surface parts of faults are subjected to principal stresses oriented either horizontally or vertically. Therefore, the MSD must be weakly coupled, either due to high fluid pressures or low-friction fault zone materials, or both.

[5] Because of the excellent exposure of undeformed protoliths, altered and sheared rocks at the seafloor, the documented seismicity at depth [Abers et al., 1997], and hydrothermal activity [Kopf et al., 2003; Speckbacher et al., 2011] the MSD is a prime candidate to study the effects of chemical and microstructural changes in rocks induced by shearing. Here, we present data from samples collected on the surface of the MSD and in its vicinity during cruise SO203 [Devey, 2009] of the R/V Sonne. The sampled suite of rocks comprises undeformed mafic protoliths, cataclasites and mylonites. Based on microstructural observations, we find that (1) plastic deformation of the mylonites occurred after intense metasomatic alteration of the initially brittle protoliths and (2) that fluid-governed addition of material occurred through repeated syn-kinematic stressdriven fluid-rock interactions. The latter implies repeated, pore pressure induced embrittlement of the otherwise ductile fault rock. We give an account of the chemical changes to the Moresby Seamount protolith induced during fracturing, cataclasis, and plastic mylonitization, and then focus on quantifying chemical flux and the source of fluids. We also document the changes in mineralogy and microstructure that go along with chemical change, and discuss the consequences for shear zone strength and deformation mechanisms. Our aim is to show how metasomatic changes can weaken fault rocks, lead to strain localization, and the sustained operation of shear zones under low flow stresses including a low-stress brittle-plastic transition.

\section{Tectonic Setting}

\subsection{Woodlark Rift}

[6] The Woodlark Rift (Papua New Guinea), the Gulf of Aden (Red Sea) and the Laptev Sea (Arctic Ocean) are tectonic settings where an active midocean ridge terminates along strike into an area of continental rifting [e.g., Van Wijk and Blackman, 2005; Little et al., 2007]. Today the westward propagating tip zone of the Woodlark Rift (Figure 1) is extending thickened crust of the Papuan Peninsula. During the opening of the Coral Sea in the Paleocene, the Papuan Peninsula developed as a crustal fragment detached from the Australian plate 


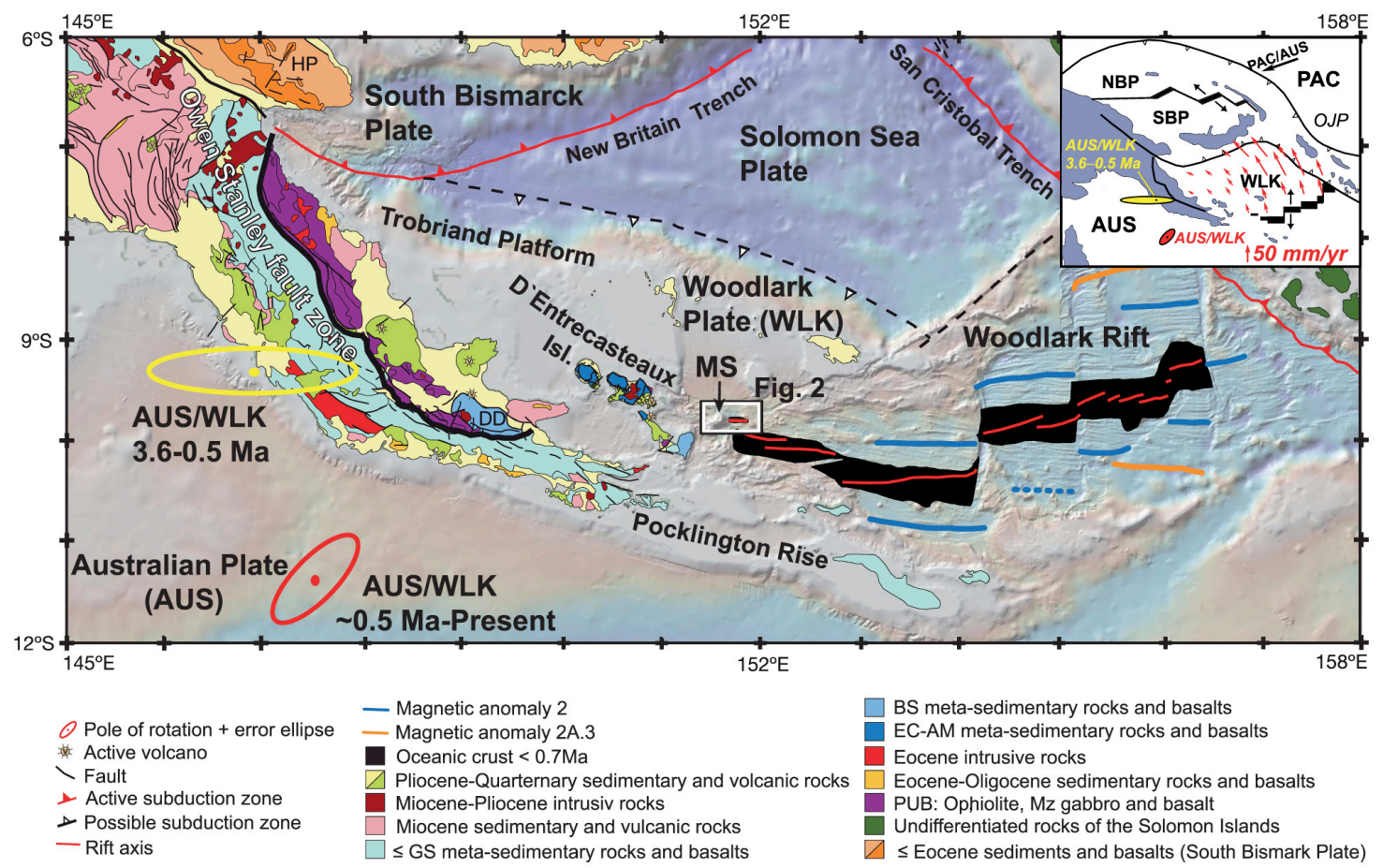

Figure 1. Tectonic and geologic map of southeast Papua New Guinea (adapted by permission from Macmillan Publishers Ltd [Baldwin et al., 2004]), including magnetic anomalies [Taylor et al., 1999]. Poles of WLK-AUS rotation for 3.6-0.5 Ma [Taylor et al., 1999] and GPS-derived pole of present-day WLK-AUS rotation [Wallace et al., 2004] are shown. Background is shaded Digital Elevation Model from GeoMapApp (http://www.GeoMapApp.org). Inset [after Baldwin et al., 2004] shows microplates of Australian-Pacific plate boundary zone: NBP, North Bismarck Plate; SBP, South Bismarck Plate; WLK, Woodlark Plate; AUS, Australian Plate; PAC, Pacific Plate; OJP, OntongJava Plateau. Red arrows indicate present-day plate motion vectors of the Woodlark Plate relative to the Australian [Wallace et al., 2004]. DD, Dayman dome; MS, Moresby Seamount; HP, Huon peninsula. PUB, Papuan Ultramafic Belt; GS, greenschist facies; BS, blueschist facies; EC, eclogite facies; AM, amphibolite facies.

[Weissel and Watts, 1979]. The architecture of this crust was shaped during underthrusting beneath the Dabi volcanic arc complex in the Eocene, resulting in the metamorphism of the Owen-Stanley metamorphics and juxtaposition of metamorphics and Papuan Ultramafic Belt (PUB) ophiolites [Davies, 1971; Davies and Jaques, 1984; Davies and Warren, 1988]. Earlier, northward subduction had ceased, and in the Paleocene ( $\sim 58 \mathrm{Ma})$ the ophiolites were obducted southward over the Owen-Stanley metamorphics [Lus et al., 2004]. The PUB represents oceanic lithosphere formed in fore-arc or back-arc basins and then emplaced during arc-continent collision [Baldwin et al., 2012, and references therein]. The Late Cretaceous to Early Paleocene PUB is exposed onshore as $16-21 \mathrm{~km}$ thick unit in the hanging wall of the Owen Stanley fault zone (Figure 1) [Davies, 1971; Davies and Jaques, 1984]. The extension of the PUB to the southeast stays debated since only the Moresby Seamount is well dated [Baldwin et al., 2012]. There, crustal extension is accommodated along the MSD within latest
Cretaceous to early Paleocene (66 Ma) ophiolites [Monteleone et al., 2001]. These ages are contemporaneous with the various ophiolite-like fragments in the PUB, however, mafic rocks drilled from Moresby Seamount ODP sites are geochemically diverse from the PUB [Brooks and Tegner, 2001]. Yet, the wide range of geochemical data may be explained by formation of the PUB in fore-arc or back-arc basins of a supra-subduction zone [e.g., Stern, 2004]. A tectonic setting facilitating the wide range of geochemical signatures (fore-arc, back-arc, islands arc and NMORB) recorded in ophiolitic fragments outcropping on the Papua New Guinea Island and the Woodlark Basin.

[7] Seafloor spreading began $6 \mathrm{Ma}$ ago (Figure 1) (chron 3A.1) in the easternmost Woodlark Basin [Taylor et al., 1999] propagating westward, although extension started synchronously along the entire length of individual spreading segments [Goodliffe et al., 1997]. Rifting at a rate of $20-40 \mathrm{~mm} \mathrm{yr}^{-1}$ has produced $100-200 \mathrm{~km}$ of extension along the modern spreading axis and has split the Papuan 

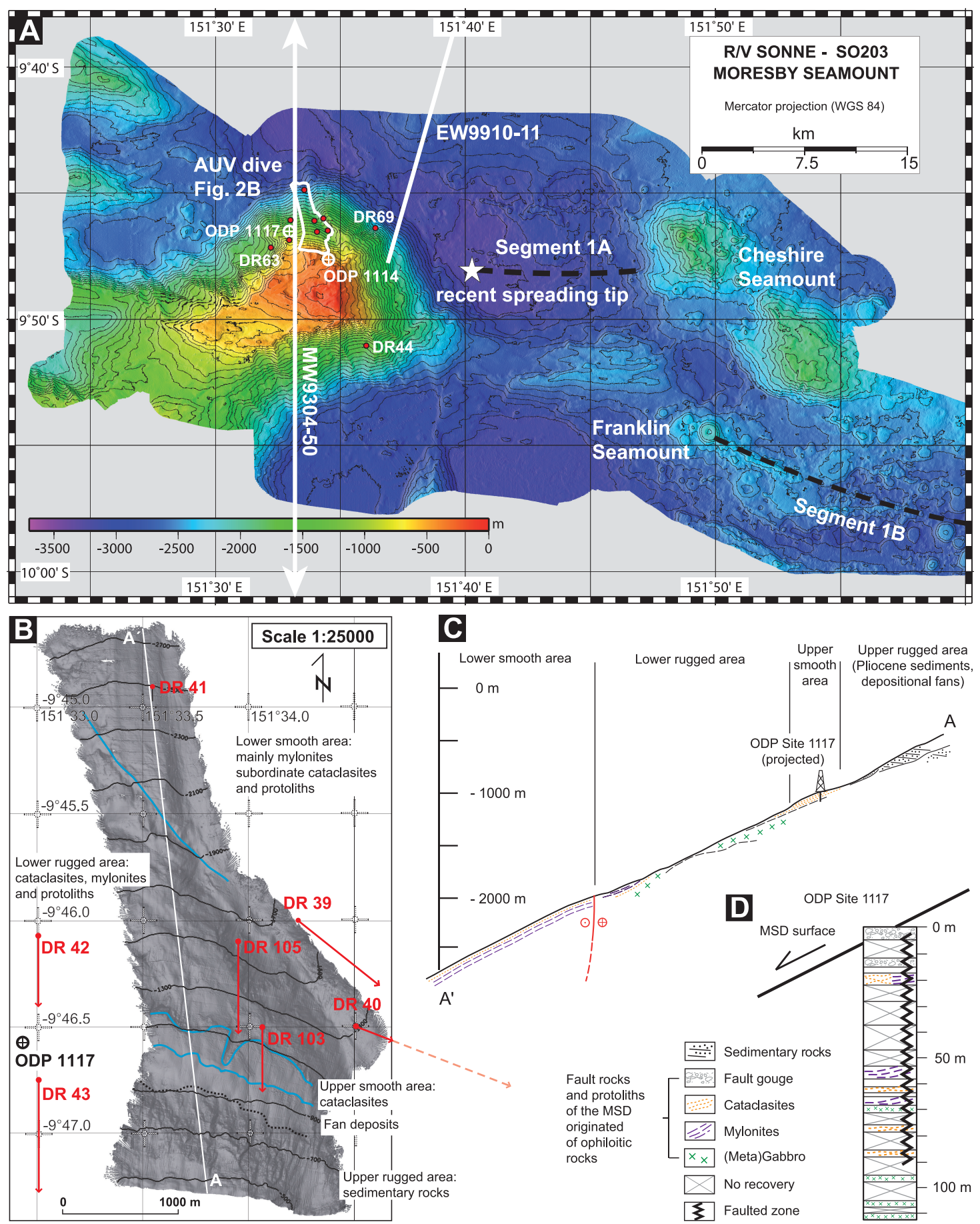

Figure 2. (a) Bathymetric map of Moresby Seamount and the transition from rifting to seafloor spreading, generated from R/V Sonne 203 multibeam echosounder data (resolution of $25 \mathrm{~m}$ ). The Moresby Seamount detachment (MSD) outcrops on the northern slopes of Moresby Seamount. The youngest spreading axis segment (Segment 1A [Goodliffe and Taylor, 2007]) lies immediately east of Moresby Seamount. Cheshire Seamount is a submarine volcano at the eastern end of segment 1A. White lines indicate traces of the seismic profiles shown in Figure 3. (b) High resolution map of the MSD from autonomous underwater vehicle (AUV) bathymetry (resolution of $2 \mathrm{~m}$ [Speckbacher et al., 2011]). Blue lines indicate domain boundaries; lowermost blue line also marks trace of strike-slip fault. Positions and run length of dredge stations relevant for this study and position of ODP site 1117. (c) Interpreted cross section (A-A') through the MSD and position of the projected ODP Site 1117. See text for discussion. (d) Compiled litho$\log$ representation of ODP Site 1117, modified from Kopf et al. [2003]. Note the consensus of the structural window in the lower rugged area and gabbro recovery in the lowermost part of ODP Site 1117. 


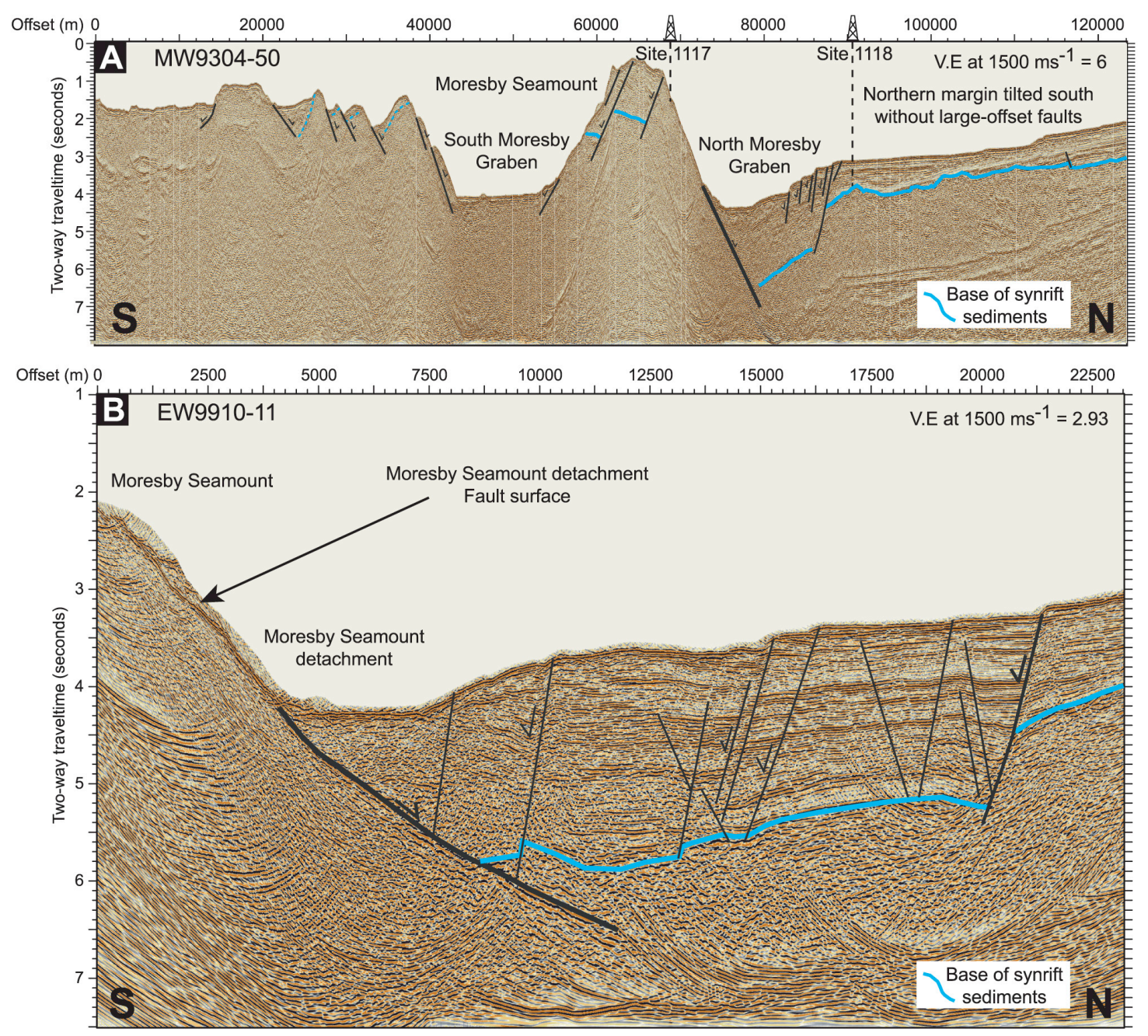

Figure 3. (a) Six-channel seismic (SCS) line MW9304-50 across Moresby Seamount and (b) multichannel seismic (MCS) line EW9910-11 across the Moresby Seamount detachment (MSD) to the west of the rifting-spreading transition (both after Goodliffe and Taylor [2007]). The location of the seismic lines is marked in Figure 2. In Figure 3a, SCS line MW9304-50 shows Moresby Seamount as a highly asymmetric horst. The basin in the south (South Moresby Graben) is a more or less symmetric Graben structure while the basin to the north (North Moresby Graben) is bounded by a single, north-dipping detachment fault (MSD) which is exposed on the northern slope of Moresby Seamount. ODP Site 1118 is projected from its true location $1.5 \mathrm{~km}$ to the east. ODP Site 1117 is projected from its true location $0.7 \mathrm{~km}$ to the west. In Figure 3b, the MCS line EW9910-11 images in detail the low angle MSD and the highangle, antithetic faults bounding the halfgraben in the north. The MSD is seismically active and earthquake focal mechanisms indicate a normal sense of motion consistent with the view that the footwall of the MSD represents a block of exhumed deeper crust [Abers et al., 1997]. See text for discussion.

paleo-peninsula to form the Woodlark and Pocklington Rises as rifted margins. Geodetic data suggest recent rates about 30\% slower [Wallace et al., 2004], in response to reorganization in spreading kinematics 500 ka ago (see Figure 1) [Goodliffe et al., 1997].

\subsection{Moresby Seamount}

[8] Moresby Seamount at $9^{\circ} 49^{\prime} \mathrm{S} / 155^{\circ} 35^{\prime} \mathrm{E}$ is located east of the D'Entrecasteaux Islands (Figures 1 and 2), an east-west trending series of physiographic highs consisting of metamorphic core complexes of Neogene age. These have accommodated much of the continental extension, have led to rapid unroofing of high-grade metamorphic rocks from $>10$ kbar $(35 \mathrm{~km})$ and $570-730^{\circ} \mathrm{C}$ to the subsurface, and are still actively uplifting [Hill et al., 1992; Baldwin et al., 1993; Little et al., 2011]. Multichannel seismic profiles across Moresby Seamount (Figure 3) reveal a northward-dipping normal fault that maintains a dip of $\sim 30^{\circ}$ to about $9 \mathrm{~km}$ depth [Mutter et al., 1996], and is known to generate large earthquakes 
$(\mathrm{Mw} \sim 6.2$; all events are less than $10 \mathrm{~km}$ deep and most are within about 5-6 km of the seafloor, see Abers et al. [1997] for details). Faulting and uplift at Moresby Seamount are estimated to have begun within the last $3.5 \mathrm{Ma}$ based on the first occurrence of fault rock talus found in the hanging wall block at ODP Site 1108 [Taylor et al., 1999]. The northern flank of Moresby Seamount corresponds to the scarp of the normal fault (Figures 2 and 3). Recent autonomous underwater vehicle (AUV) mapping showed that active deformation at Moresby Seamount is partitioned into dip-slip normal and sinistral strikeslip faulting, directly reflecting plate kinematic constraints [Speckbacher et al., 2011].

\section{Moresby Seamount Detachment}

\subsection{Fault Zone Description Based on High Resolution Mapping and ODP Drillsites}

[9] During R/V Sonne cruise SO203 [Devey, 2009] a total of 10 dredge runs (labeled DR below) recovered rocks of the Moresby Seamount, and AUV high resolution mapping allowed assessment of the tectonic geomorphology (see Speckbacher et al. [2011] for details and Figure 2). The upper rugged area (Figures $2 \mathrm{~b}$ and $2 \mathrm{c} ; 500-950 \mathrm{mbsl}$ ) is made up of Pliocene-Pleistocene clastic sediments (DR43, ODP Site 1114. The upper smooth area (Figures $2 \mathrm{~b}$ and $2 \mathrm{c}$ ) is an extremely planar, north-dipping surface between 950 and 1100 mbsl. DR103 recovered only mafic basement with an intense cataclastic overprint (i.e., the cataclasites). We interpret this surface as the exposed top of the MSD. The upper boundary of the lower rugged area (Figures $2 \mathrm{~b}$ and $2 \mathrm{c}$ ) is a steep erosional cliff, which cuts a few tens of meters into the cataclastic surface above. Between 1100 and $\sim 2000 \mathrm{mbsl}$, rough topography is defined by erosional scarps. Structurally, this area, called lower rugged area, is a window into the footwall of the cataclasite-covered surface above. DR42 and DR105 obtained a mix of cataclasites, mylonites, and undeformed mafic basement (i.e., the protoliths). The lower smooth area (Figures $2 b$ and $2 c$ ) is a planar and structurally smooth surface. DR41 recovered mainly mylonites (and subordinate cataclasites), indicating that the surface forms the top of a ductile mylonite zone. DR39 and DR40 are arranged in a straight NW-SE striking depression close to the upper boundary of the lower smooth area. Here tectonic geomorphology suggests a structural discontinuity (see Speckbacher et al. [2011] for details) and relevant rock types are mylonites, possibly from a slightly deeper structural level, as well as protolith rocks.
[10] ODP drillsite 1117 (Figures 2c and 2d) recovered talc-chlorite-serpentinite clayey fault gouge in the uppermost 12 mbsf [Taylor et al., 1999]. The fault gouge is followed by a $50 \mathrm{~m}$ wide section of very low recovery made up by ultracataclasites and mylonites, representing plastic and intermittent brittle deformation [Kopf et al., 2003]. This intensively deformed fault zone horizon, showing both brittle and plastic deformation, reaches a depth of ca. 90 mbsf, where slightly deformed to undeformed metagabbros become dominant. ODP site 1117 can be projected into the profile shown in Figure $2 \mathrm{c}$ and is in good agreement with our dredge results and interpretation of the structural window exposing protoliths in the lower rugged area (Figure 2c). Since the lower rugged area represents the same less deformed to undeformed structural level (dominated by metagabbros) that has been drilled at the lowermost part of ODP site 1117.

\subsection{Protoliths and Fault Rocks Related to the MSD}

[11] The MSD on the N and NNW slopes of Moresby Seamount exposes intensely deformed rocks (Figure 4). The lithologies involved in faulting are sedimentary rocks of Pliocene-Pleistocene age and their substratum, Paleogene or older [Taylor and Huchon, 2002] mafic basement of the extensive PUB [Little et al., 2007; Baldwin et al., 2012]. The basement fault rock data on the protoliths, cataclasites and mylonites serve as a framework for the later discussion on fluid flow and mass transfer along the MSD.

\subsubsection{Protolith}

\subsubsection{Gabbro}

[12] The footwall of the MSD consists of greenishgray gabbros (Figure 4a) composed of equal amounts of plagioclase and clinopyroxene (Figure 5a) with associated dendritic magnetite, ilmenite and minor xenomorphic quartz. Secondary minerals are chlorite and epidote. The gabbros show considerable variations in grain size, from fine grained $(0.5-1 \mathrm{~mm})$ to coarse grained (maximum crystal sizes observed were $\sim 6 \mathrm{~mm}$ ), and vary from a granular microstructure to microstructures showing a weak alignment of plagioclase and clinopyroxene grains. This microstructural variation is accompanied by hydrothermal alteration and changes in mineralogy, with clinopyroxene altered to green amphibole and chlorite. The mineralogy and microstructure of gabbros drilled at ODP Site 1117 are described as being similar to those of high-level gabbros occurring in ophiolites [Taylor 
and Huchon, 2002], and are similar to the gabbros investigated in this study.

\subsubsection{Dolerite}

[13] Dolerite (Figure 5b) was found in DR43 and DR103 and represents a minority of the recovered protoliths with respect to the gabbro. Dolerites are composed of clinopyroxene and partially sausseritized plagioclase often inter- or overgrown by dendritic magnetite and iron oxides. Clinopyroxene is sometimes replaced by chlorite. Recovered rock samples are occasionally moderately altered; all are fine to medium-grained with ophitic microstructures.

\subsubsection{Cataclasite}

[14] The transition from the protoliths to intensely deformed cataclasites is gradational. Cataclasites display greenschist-grade to sub-greenschist-grade brittle deformation fabrics, namely multistage extensional fractures filled with quartz \pm epidote or
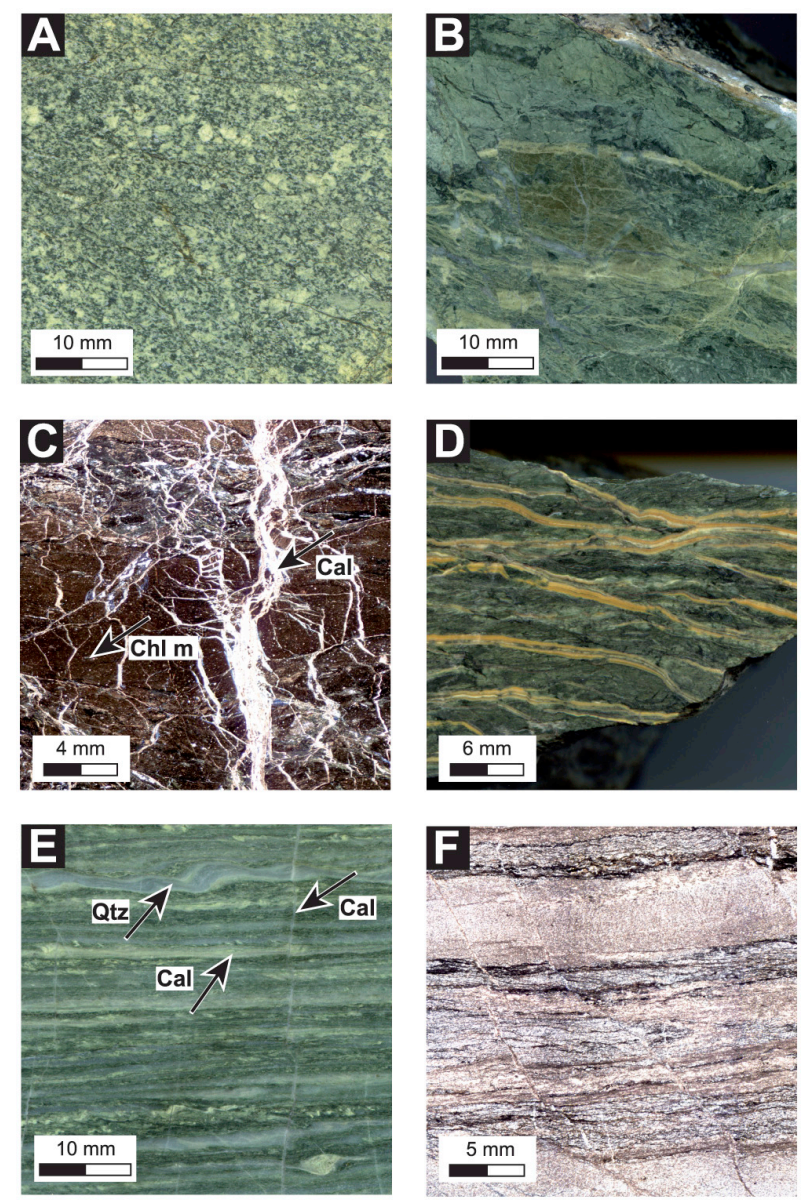

carbonates (Figure 5c). Cataclasite fabrics change from a fractured and vein-in-host rock fabric to a cataclastic fabric displaying identifiable protolith clasts (Figure 5d), with the most deformed parts showing a very fine-grained ultracataclastic fabric (Figure 5d). The veins are randomly oriented and filled with fine- and coarse-grained, newly crystallized minerals. The cataclasites formed by fluidassisted fracturing of the protolith (gabbro and dolerite). Clasts in the cataclasites are exclusively derived from undeformed and/or fractured protolithic rocks (Figure 5d). Less fractured clasts locally preserve clinopyroxene and plagioclase, but commonly clasts show pervasive alteration of these minerals to chlorite and epidote, and minor white mica and calcite. Areas of high strain are characterized by a high matrix to clast ratio, resulting in ultracataclastic microstructures. The ultracataclastic matrix comprises fine grained fragments of dominantly chlorite and plagioclase, and minor epidote and quartz. Transition to semi-ductile fabrics is recorded in chlorite-rich phyllonites. In these samples (found in DR103 and DR105), the foliation is cut by multistage shear bands and plagioclase porphyroclasts show incipient dynamic recrystallization tails. Undeformed to strongly deformed veins

Figure 4. (a, b, d, and e) Sawcut and (c and f) thin section (crossed-polarized transmitted light) photographs of protolith and fault rocks. Orientation planes are perpendicular to foliation and parallel to lineation. Figure $4 \mathrm{a}$ shows undeformed medium-coarse grained (grain size 1-3 mm) metagabbro (dredge, DR39-6A) with subhedral feldspar and pyroxene. Figure $4 \mathrm{~b}$ shows chloriterich cataclasite (DR103-1C) that is intensely fractured and displays grain-size reduction and rotation. Figure $4 \mathrm{c}$ shows faulted and hydrothermally altered chlorite-rich cataclasite (DR103-1E) with intense fracturing and calcite veining. Dark brown areas define the cataclastic matrix consisting of retrogressed and now fine grained host rock and abundant chlorite. Figure 4d shows foliation-parallel anastomosing hydrofractures with crack-seal structures in a chlorite-phyllonite (DR105-1A). The crack-seal structures consist of cyclically grown calcite fibers indicating intermittent hydraulic fracturing. Figure $4 \mathrm{e}$ shows a typical mylonite sample (DR40-2A). Foliation consists of layers of quartz, calcite and mafic host rock assemblage. Note the youngest generation of undeformed fine-grained calcite veins, crosscutting the foliation at high angles. Figure $4 \mathrm{f}$ shows deformation fabric of fine-grained quartz- and calcite-rich mylonite (DR41-1B). Bright layers consist dominantly of quartz and calcite, while the darker, finegrained layers and aggregates are formed by chlorite, quartz, feldspar and mica. Chl $\mathrm{m}=$ chlorite matrix, $\mathrm{Qtz}=$ quartz, $\mathrm{Cal}=$ calcite . 
Geochemistry

of quartz and calcite, with minor chlorite and pyrite provide the youngest evidence of fluid-rock interaction.

\subsubsection{Mylonite}

[15] In the mylonites syntectonically formed quartz and calcite are dissipated throughout the intensely foliated rock matrix. Protomylonites still display rotated clasts of the mafic host rock assemblage (Figure 5e). Identifiable are fractured pyroxene (Figure 5f) and plagioclase as well as plastically deformed layers of quartz and calcite plus minor chlorite. Protomylonites have sigma clasts, flanking structures, asymmetric boudinage as well as rotated and boudinaged quartz and calcite veins. Mylonites and very fine-grained ultramylonites (Figure $5 \mathrm{~g}$ ), mostly from the lower part of the MSD (mainly recovered from DR41, see Figure 2b) contain significant amounts of quartz and calcite plus some chlorite. These mylonites have a tight foliation and a well developed stretching lineation. Shear sense indicators are rare, however, dynamically recrystallized quartz grains show shape preferred orientations oblique to the compositional mylonitic foliation (Figure 5h). Quartz microstructures reveal subgrain rotation and lower stress (BLG II) [Stipp et al., 2002] bulging recrystallization (Figure 5h).
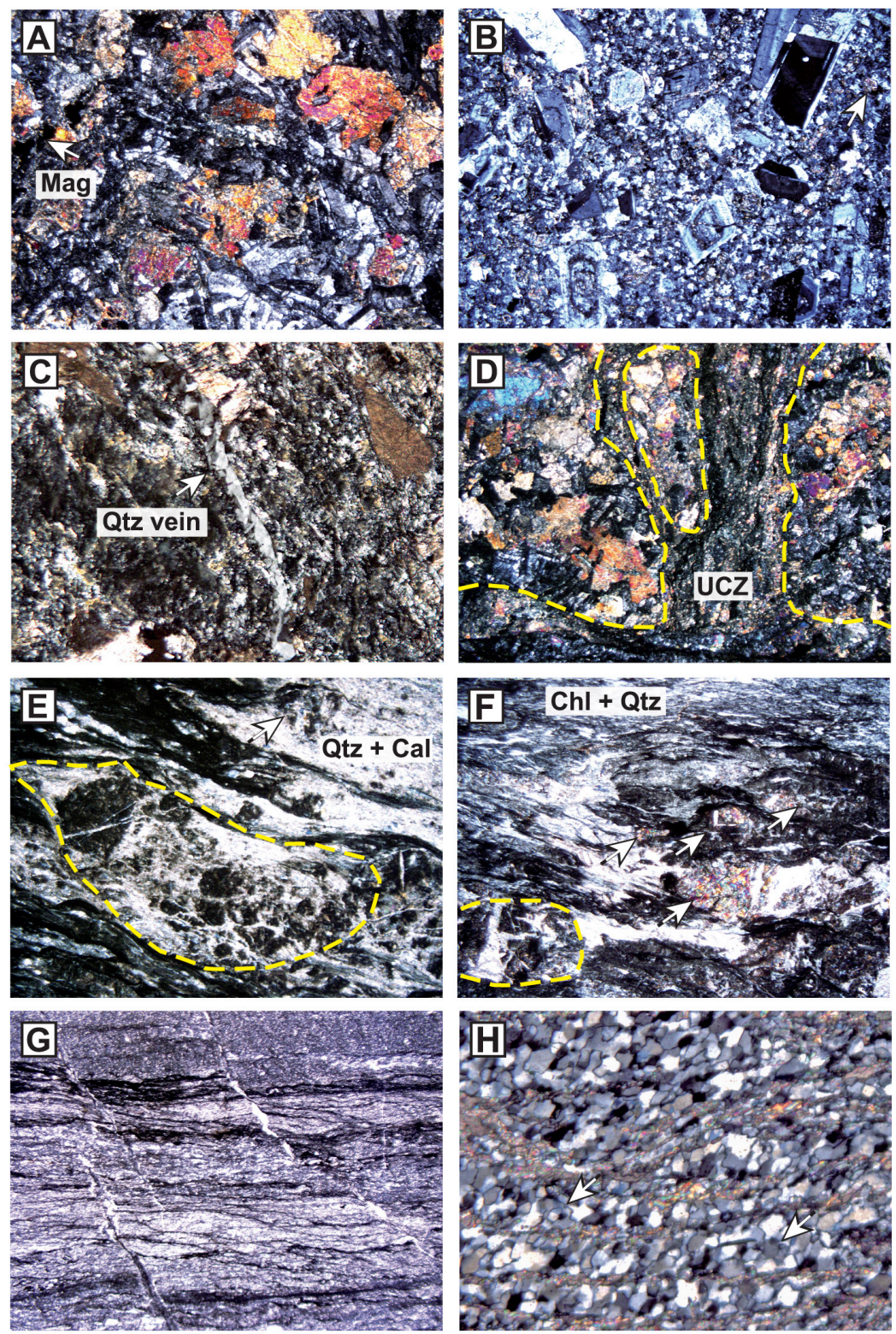

Figure 5 

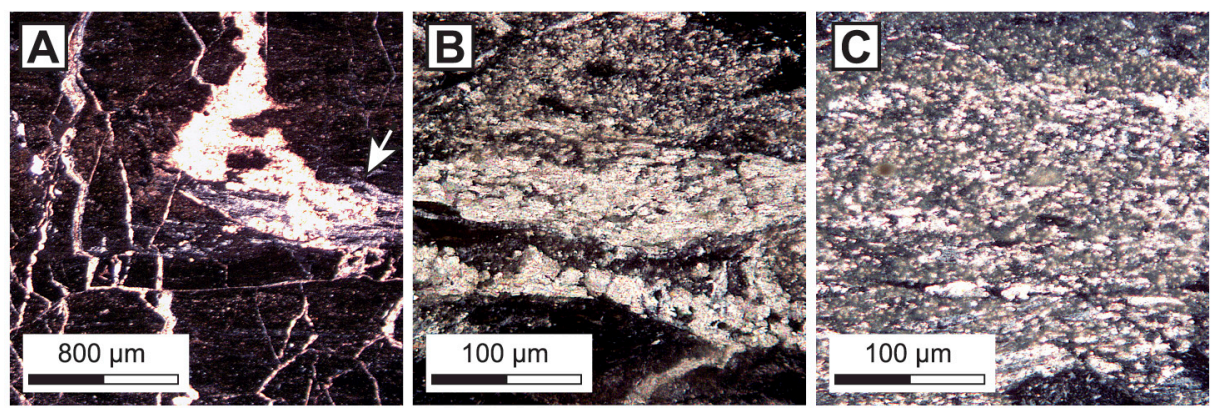

Figure 6. Calcite and quartz veins and their incorporation into the fault rocks. (a) Crosscutting veins of calcite and minor quartz which are locally stretched out (arrow) as a response to ongoing shearing and foliation formation (DR103-1C). (b) Vein with elongated and hence sheared calcite grains overprinted by fracturing (DR103-1E). (c) Calcite grain-size reduction and dissemination (DR103-1E) generated by processes like ongoing cataclasis, plastic shearing and precipitation during brittle emplacement, leading to further weakening of the fault rocks.

Calcite is arranged in layers of stretched aggregates (Figures $5 \mathrm{~h}$ and $6 \mathrm{~b}$ ) and/or disseminated in the mylonitic matrix (Figure 6c).

\subsection{Sample Selection}

[16] Sampling the MSD at the seafloor by dredging [Devey, 2009; Speckbacher et al., 2011] was principally guided by the results of high-resolution mapping with the AUV. Therefore, dredges DR44, DR63 and DR69, outside of the AUV dive (Figure 2a), are excluded from this study. Even though DR42 and DR43 are slightly positioned outside, maps of backscatter intensity [Devey, 2009] and recovered rocks provide evidence that these dredges contain rocks of the MSD. For the dredge runs, the start and end points are shown in Figure 2b; all dredge runs were carried out uphill. In Tables 1 and 2 each analyzed sample shows a number before the hyphen indicating the dredge run number, whereas the number behind the hyphen is the particular sample number of the relevant dredge.

[17] As pointed out by Grant [2005], in carrying out geochemical mass balance calculations it is critical to obtain as close an approximation to the actual protolith as possible. For the MSD we can use following qualifiers for the classification into protolith, and fault rocks:

[18] The evaluation of the relevant dredges DR39, DR40, DR41, DR42, DR43, and DR105 showed a macroscopically and microscopically very homogeneous protolith. Statistics of all recovered dredge samples along the MSD, indicate that fault rocks derive from the same type of protolith, since no other undeformed lithologies were recovered.

[19] The assessment of mineralogy, alteration and microstructure, as given in section 3.2., suggests

Figure 5. Photomicrographs (all crossed polarizers except Figure 5g) showing protoliths (Figures 5a and 5b) and progressive development of alteration and deformation microstructures in Moresby Seamount detachment (MSD) fault rocks. (a) Relatively fresh gabbro (DR43-2B) with plagioclase, clinopyroxene, magnetite, and minor alteration products. Long dimension is $3 \mathrm{~mm}$. (b) Dolerite (DR105-2A) displaying an ophitic texture with coarse grains made up of large plagioclase laths and smaller already altered pyroxene. Long dimension is $3 \mathrm{~mm}$. (c) Vein-in-host rock fabric of an altered metagabbro (DR39-6A). Extensional quartz veins document the onset of brittle deformation in the otherwise undeformed metagabbro. The gabbroic host rock displays alteration of pyroxene to hornblende and chloritization. Long dimension is $1.5 \mathrm{~mm}$. (d) Metagabbro (DR43-3C) with fine-grained ultracataclastic zone (UCZ, indicated by dashed yellow line) containing a protolith clast. This fabric documents incipient cataclastic deformation of the protolith. Long dimension is $6 \mathrm{~mm}$. (e) MSD protomylonite (DR42-3C) showing mafic clasts of cataclastically faulted protoliths (dashed yellow outlines) indicating that sampled mylonites originated from the gabbroic protolith and overprint the cataclastic fault rocks. Long dimension is $3 \mathrm{~mm}$. (f) Chlorite and quartz-rich mylonite (DR42-3C) showing a cataclasite clast (dashed yellow outlines) and deformed pyroxenes (arrows), again documenting the progressive evolution of fault rocks from the MSD protolith. Long dimension is $3 \mathrm{~mm}$. (g) Fine-grained mylonite (DR41-1B) showing chlorite-rich layers (darkish areas) and documenting the importance of infiltrated quartz and calcite causing a strong mylonitic foliation. Crosscutting calcite veins indicate episodic stress build-up and extensional fracturing. Long dimension is $6 \mathrm{~mm}$. (h) Deformation microstructure of a quartz mylonite (DR40-2A) infiltrated by some calcite (in layers) indicative of progressive weakening. Large quartz grains $(50-80 \mu \mathrm{m})$ formed by subgrain rotation recrystallization and local bulges and recrystallized grains (arrows) along sutured grain boundaries are indicative of bulging recrystallization. Long dimension is $1.5 \mathrm{~mm}$. Mag = magnetite, $\mathrm{Qtz}=$ quartz, $\mathrm{Cal}=$ calcite . 
Table 2. Sr and Nd Isotopic Data From the Moresby Seamount Detachment ${ }^{\mathrm{a}}$

\begin{tabular}{cccccc}
\hline Sample & ${ }^{87} \mathrm{Sr} /{ }^{86} \mathrm{Sr}$ & $\pm 2 \sigma$ & ${ }^{143} \mathrm{Nd} /{ }^{144} \mathrm{Nd}$ & $\pm 2 \sigma$ & $\varepsilon \mathrm{Nd}$ \\
\hline $39-6 \mathrm{~B}^{\mathrm{b}}$ & 0.704866 & 3 & 0.512755 & 3 & 2.281337 \\
$41-3 \mathrm{~A}^{\mathrm{b}}$ & 0.704019 & 3 & 0.512902 & 2 & 5.148857 \\
$103-1 \mathrm{G}^{\mathrm{c}}$ & 0.704575 & 3 & 0.512806 & 3 & 3.277752 \\
$105-8 \mathrm{~A}^{\mathrm{c}}$ & 0.704763 & 4 & 0.512915 & 2 & 5.408495 \\
$39-4 \mathrm{D}^{\mathrm{d}}$ & 0.707385 & 3 & 0.512594 & 3 & -0.849722 \\
$40-2 \mathrm{~A}^{\mathrm{d}}$ & 0.707419 & 3 & 0.512392 & 3 & -4.805925
\end{tabular}

a 2 sigma refers to the last significant digit.

${ }^{\mathrm{b}}$ Protolith.

${ }^{\mathrm{c}}$ Cataclasite.

${ }^{\mathrm{d}}$ Mylonite.

that the examined fault rocks originate from the same protolith.

[20] The geologic/tectonic setting of Moresby Seamount is challenging in terms of geological and structural interpretation. Tectonically the MSD is often called the last continental fault to develop before crustal breakup [e.g., Mutter et al., 1996; Floyd et al., 2001], but ODP drillsites recovered dolerites and gabbros of latest Cretaceous to early Paleocene $(66 \mathrm{Ma})$ as remnants of oceanic crust [Monteleone et al., 2001]. In fact, Moresby Seamount is at the edge of continental lithosphere and crustal extension is accommodated along the MSD, whose present normal fault surface is built up by mafic rocks, likely belonging to the PUB (see chapter 2.1.). The AUV dive covers more than $2000 \mathrm{~m}$ of elevation range of the exposed MSD surface. This exposure and structural geometry of the MSD anticipate that dredge runs from the lower areas and structurally deeper levels of the exposed fault surface should recover plastically deformed rocks, whereas the cataclastic rocks should be recovered from shallower structural levels. The documented present-day geothermal gradient of $100^{\circ} \mathrm{C} / \mathrm{km}$ [Taylor et al., 1999] implies that fault rocks can now be at the surface that were formed at temperatures above the brittle-plastic transition. The non-deformed mafic protolith rocks for the geochemical mass balance are located in structural windows exposed by erosional features and/or in strain enclaves within the shear zone.

\section{Methods of Investigation}

\subsection{Analytical Techniques}

[21] Major element analyses were carried out at AcmeLabs (http://acmelab.com/) using a lithium borate fusion technique, followed by X-ray fluorescence analysis. Precision was estimated from duplicate analysis. Trace elements were determined by ICP-MS following a lithium metaborate/tetraborate fusion and nitritic digestion of a $0.2 \mathrm{~g}$ sample. Accuracy was evaluated by comparison with international standards. A gas pycnometer operated with helium was used to experimentally determine the densities of rock samples (see Table 1).

[22] Samples selected for isotope geochemistry were first crushed to small pieces and then washed in deionized water. $\mathrm{Sr}$ and $\mathrm{Nd}$ isotope analyses were carried out on leached rock chips $(2 \mathrm{n} \mathrm{HCl}$ at $70^{\circ} \mathrm{C}$ for one hour and triple rinsed with ultrapure water thereafter). Element chromatography followed the methods given in Hoernle and Tilton [1991], and Hoernle et al. [2008]. Sr-Nd isotopic ratios were measured at GEOMAR on a TRITON thermal ionization mass spectrometer (TIMS) operating in static multicollection mode.

[23] $\mathrm{Sr}$ and $\mathrm{Nd}$ isotopic ratios are mass-bias corrected relative to ${ }^{86} \mathrm{Sr} /{ }^{88} \mathrm{Sr}=0.1194$ and ${ }^{146} \mathrm{Nd} /{ }^{144} \mathrm{Nd}=0.7219$, respectively. NBS987 measured along with the samples gave ${ }^{87} \mathrm{Sr} /{ }^{86} \mathrm{Sr}=0.710237 \pm 0.000011(\mathrm{~N}=5)$ and the sample data is reported to a normalized NBS987 value of ${ }^{87} \mathrm{Sr} /{ }^{86} \mathrm{Sr}=0.710250$. The in-house $\mathrm{Nd}$ monitor SPEX measured along with the samples gave ${ }^{143} \mathrm{Nd} /{ }^{144} \mathrm{Nd}=0.511694 \pm 0.000007(\mathrm{~N}=5)$ and sample data is reported to a normalized SPEX value of 0.511715 which corresponds to a calibrated La Jolla-value of ${ }^{143} \mathrm{Nd} /{ }^{144} \mathrm{Nd}=0.511850$.

\subsection{Mass Balance Calculations}

[24] The opening of geochemical systems to alteration may lead to mass transfer of specific elements [Akella, 1966; Gresens, 1967]. Evaluating the chemical gains and losses are fundamental for understanding the associated geological process. As emphasized by Gresens [1967], data from whole rock chemical analysis show only relative changes in bulk rock chemical compositions. To quantify the chemical gains or losses associated with mass transfer, elemental concentrations in altered rocks have to be normalized to elements considered immobile during the alteration of the protolith [Gresens, 1967; Grant, 1986]. Some major elements like $\mathrm{Al}, \mathrm{Ti}$ and $\mathrm{P}$ are often reported as being immobile. An even better reference frame may be provided by potentially immobile trace elements such as $\mathrm{Zr}, \mathrm{Y}$ and $\mathrm{Nb}$ [Grant, 1986; Marquer and Burkhard, 1992; Baumgartner and Olsen, 1995]. Many studies propose immobility of $\mathrm{Al}$ and $\mathrm{Zr}$ [Selverstone et al., 1991; Demény et al., 1997; Steyrer and Sturm, 2002], and Ti, Zr, Y and P [O'Hara, 1988; Oliver et al., 1993]. However, in other cases Al [O'Hara, 
1988] and Ti [Selverstone et al., 1991] have been reported to be mobile in some geologic environments. This indicates that the relative mobility of elements is sensitive to fluid composition and the deformational environment [e.g., Streit and Cox, 1998].

[25] Figure 7 displays analytical data from eight protolith-, nine cataclasite-, and eleven mylonitesamples, dredged from the MSD, in isocon diagrams [Grant, 1986] to illustrate compositional changes in the course of cataclasis and/or mylonitization. As pointed out by Grant [1986], elements plotting on a single straight line through the origin denote elements of equal chemical concentration ratios in the protolith and the altered rock. Such a line is called an isocon and is given by the equation

$$
C^{A}=\left(M^{0} / M^{A}\right) C^{0}
$$

where $C$ is concentration, $M$ is mass; and the $O$ and $A$ superscripts refer to the original and altered rock, respectively. A best fit isocon that is consistent with petrographic observations and the geological process involved designates the immobile elements during alteration. The slope of the isocon reflects the overall change in mass relative to $M^{0}$. Elements plotting above the isocon were gained during alteration, whereas those plotting below were lost. The gain or loss of elements can be quantified using the slope of an isocon $\left(M^{0} / M^{A}\right)$. Grant's [1986] approach requires that the altered rock originated from the same protolith. Sampling the MSD at the seafloor by dredging [Devey, 2009; Speckbacher et al., 2011] was principally guided by the results of high-resolution mapping with the AUV. Even though we have to acknowledge that dredging is not comparable in spatial resolution to field work on land, this is the best possible approach to geological field work under water. The additional important qualifier for rock types we used is the absence or presence of deformation and associated microstructures. It is further critical to cope with problems regarding the heterogeneity of the protolith. Sampling the altered fault rocks is generally less problematic [Grant, 2005]. Thus, we introduced homogeneity bars to the isocon plots (Figures 7 and 9), which were constructed according to the method of Steyrer and Sturm [2002]. The horizontal bars provide direct information of the protolith compositional range, whereas the vertical ones represent the spread within the altered rock. The length of bars (exemplary for the protolith and horizontal bar, respectively) is given by:

$$
\frac{C_{\max }^{0}-C_{\min }^{0}}{\sum_{i=1}^{n} C_{\min }^{0}} n
$$

where $C_{\max }^{0}$ is the highest concentration of original element concentration $C^{0}$ (in wt $\%$ for major elements, ppm for trace elements) from the protoliths $(n=8), C_{\min }^{0}$ is the lowest one, and $\sum_{i=1}^{n} C_{i}^{0} / n$ is the mean value of element $C^{0}$. For the vertical bar construction, the relevant variables of $C^{A}$ are applied in equation (2).

[26] The bar lengths indicate the spread normalized against the mean values of rock types for each element in the diagram (Figure 7), allowing direct comparison of respective elements, independent of their absolute concentrations [Steyrer and Sturm, 2002]. Furthermore, so-called $R$ values [Kerrich et al., 1980], which specify the range of values normalized against the mean value of major and trace elements from chosen protolith, cataclasite, and mylonite samples are listed in Table 1. The degree of elemental homogeneity is determined with the help of such $R$ values, using following classification [Kerrich et al., 1980]:

$$
\begin{gathered}
0<R \leq 0.5 \text { homogeneous } \\
0<R \leq 1.0 \text { heterogeneous } \\
1.0<R \text { very heterogeneous }
\end{gathered}
$$

Relative volume changes are given by the volume factor $\left(F_{V}\right)$, which is defined as the ratio of equivalent rock volumes before and after alteration:

$$
F_{V}=\left(C_{i}^{0} / C_{i}^{A}\right) \times\left(\rho^{0} / \rho^{A}\right)
$$

[Gresens, 1967], where $C_{i}^{0}$ and $C_{i}^{A}$ is the concentration of immobile element $\mathrm{i}$ of original and altered rock, respectively, and $\rho^{0}, \rho^{A}$ are the densities of original and altered rock. Measured average rock densities (Table 1) are 3.05, 2.90 and $2.76 \mathrm{~g} \mathrm{~cm}^{-3}$ for protolith, cataclasite and mylonite, respectively and are in agreement with known data of ODP Site 1117 [Kopf, 2001]. The relation of material gains / losses during rock alteration to associated volume changes are derived by following equation:

$$
X_{n}=F_{V} \times\left(\rho^{A} / \rho^{0}\right) \times C_{n}^{A}-C_{n}^{0}
$$

[Gresens, 1967], that indicates gain or loss for each element $n$.

\section{Results}

\subsection{Major and Trace Elements and Mass Transfer Calculations}

[27] The analytical results used in this study are given in Tables 1 (Major and trace elements, whole rock) and 2 (Isotope analyses). Isocon plots were constructed from the major and trace element data 
to depict the chemical transformation from (1) protolith to cataclasite (Figure 7a) and (2) protolith to mylonite (Figure 7b). The microstructural observations (see section 3.2) suggest that the latter
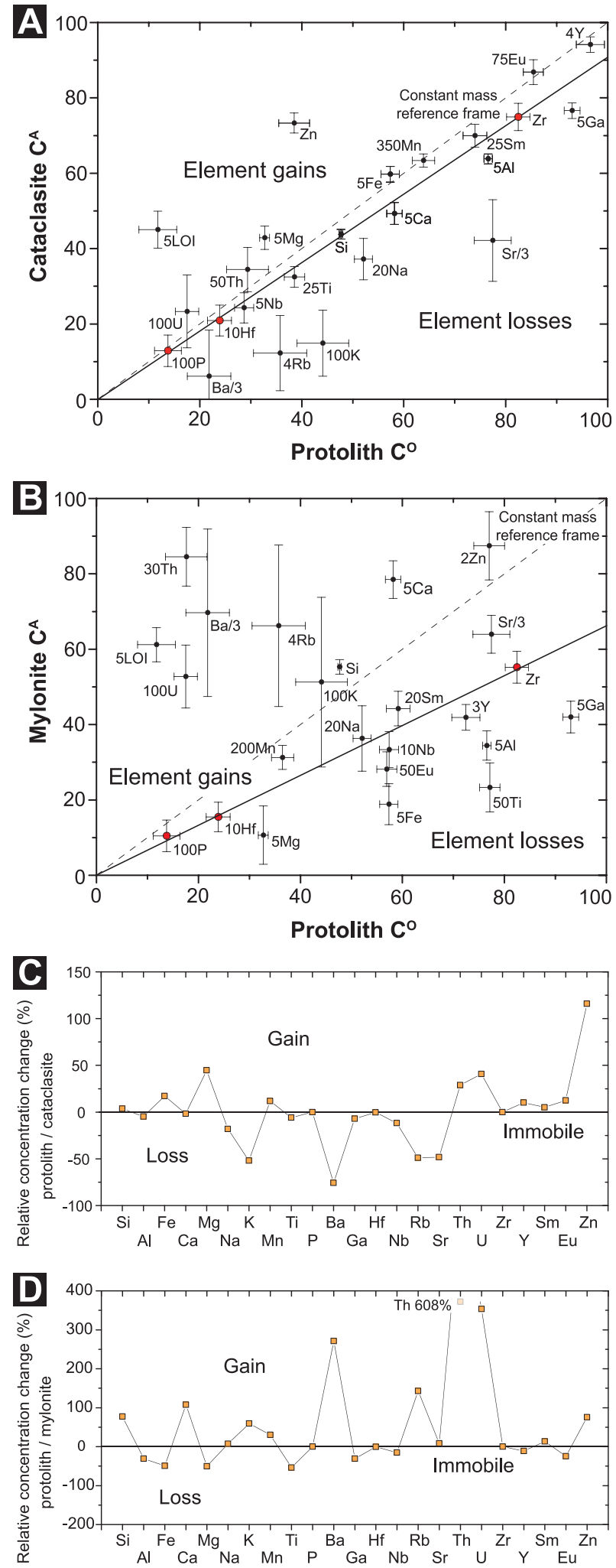

transformation can be considered as a results of overprinting cataclastic (early) and mylonitic (later) deformations. We use a reference frame for the calculation of material gains and losses during syntectonic alteration as defined by $\mathrm{Zr}$, Hf and $\mathrm{P}$, which plot on a straight line in Figures 7 and 9 and are generally considered as immobile.

[28] The $R$ values (Table 1) for the major elements of the protolith typically vary between $0.08(\mathrm{Si})$ and $1.27(\mathrm{~K})$, while trace elements display homogeneous distribution, except for $\mathrm{Ba}$ and $\mathrm{Rb}$, which show maximum values of 1.07 and 1.31 , respectively. All $R$ values of the protolith depict a distribution curve with an arithmetic mean of 0.629 and a standard deviation of 0.317 . The elements $\mathrm{Si}, \mathrm{Al}$, $\mathrm{Fe}, \mathrm{Ca}, \mathrm{Mg}, \mathrm{Na}$ and $\mathrm{Ti}$ are regarded as distributed relatively homogeneously in the protoliths studied, while $\mathrm{Mn}$ is heterogeneously distributed. Finally, K concentrations are heterogeneous, this characteristic remains during deformation, thus $\mathrm{K}$ is the most heterogeneously distributed major element in all types of rock in this study.

[29] The transformation of protolith to cataclasite (Figure 7a) does not generally lead to large changes in element concentrations. Elements close to the isocon correspond to small gains and losses [Grant, 2005]. However, $\mathrm{Mg}$ and to a lesser extent $\mathrm{Fe}$ and Mn were syntectonically enriched during cataclasis, while there is a depletion in $\mathrm{K}$ and $\mathrm{Na}$. The gains of $\mathrm{Mg}$ and $\mathrm{Fe}$ reflect a mineralogical change during cataclastic deformation and related metasomatism, namely the chloritization of pyroxene and amphibole. Observations under the microscope and SEM also suggest that chlorite replaces plagioclase. Chloritization, therefore, is not a simple process of in situ transformation, but rather involves the addition of other elements, such as Fe. Also the

Figure 7. Isocon diagrams of Moresby Seamount detachment (MSD) rocks. Concentrations $(C)$ are in $\mathrm{wt}^{\mathrm{t}} \%$ (oxides) or ppm (trace elements) and scaled to fit on the plot. Labels for oxides are abbreviated to the cation elements. Solid lines = constant Zr, Hf and P (red symbols) reference isocon; dashed lines $=$ constant mass reference. Homogeneity bars provide information about the compositional range within the particular MSD rock type. Slopes of isocons deviating from one indicate relative mass changes in the deformed rock. Data from Table 1. See text for discussion. (a) Isocon diagram shows the average composition of protolith $\left(C^{0}\right)$ against the average composition of cataclasite $\left(C^{A}\right)$. (b) Isocon diagram shows the average composition of protolith $\left(C^{0}\right)$ against the average composition of mylonite $\left(C^{A}\right)$. (c) Plot of element concentration in the cataclasite relative to the protolith. (d) Plot of element concentration in the mylonite relative to the protolith. 
metasomatic evolution of talc-rich mafic rocks, which have been recovered at ODP Sites 1108 and 1117 [Taylor et al., 1999], relates to an overall gain of $\mathrm{Mg}$ in these rocks. The gain of $\mathrm{Mn}$, on the other hand, may be a manifestation of sub-seafloor hydrothermal vein systems [e.g., Barnicoat and Bowtell, 1995]. The observed depletions of K and $\mathrm{Na}$ are consistent with the observation that anorthoclase and Na-rich feldspar are decomposed during alteration, and replaced by more Ca-rich plagioclase. Loss on ignition (LOI) values are also increased in cataclasites, reflecting an increase of hydrous minerals, mainly sheet silicates [e.g., Cartwright and Barnicoat, 2003]. Among the trace elements, $\mathrm{Ba}, \mathrm{Rb}$ and $\mathrm{Sr}$ were depleted during cataclastic deformation. The loss of Ba most likely relates to the alteration and partial breakdown of feldspar. $\mathrm{Sr}$ depletion relates to the alteration of plagioclase and $\mathrm{Rb}$ depletion can be linked to chloritization. The alterability of depletion in these elements is dependent on the relative abundances of each of these elements in the protolith [Clark et al., 2005]. The enrichment of $\mathrm{Zn}$ possibly reflects the evolution of hydrothermal veining and formation of sulphides during cataclasis. Generally, the changes of major and trace elements illustrated in Figure 7a can clearly be related to a mineralogical evolution expected and observed for the cataclastic overprint of the mafic protolith, i.e., process of chloritization and a general hydration of the assemblage.

[30] The isocon plot depicting the differences between the compositions of protolith and mylonite (Figure $7 \mathrm{~b}$ ) shows much stronger deviations of individual elements from the isocon than is the case for the protolith-cataclasite plot (Figure 7a). There is strong enrichment of $\mathrm{Si}$ and $\mathrm{Ca}$ in the mylonites. Both gains represent the multiple generations of quartz and calcite veins that were infiltrated syntectonically in fractures and microcracks, and then were involved in plastic deformation. Most of the calcite and quartz occurs disseminated in the matrix (Figure 6c) or as stretched stringers and layers subparallel to the mylonitic foliation (Figure 6b). The increase of $\mathrm{K}$ in the mylonites is related to hydrothermal activity and is reflected in the growth of fine-grained muscovite during mylonitization. The enrichment of $\mathrm{Na}$ is associated with pervasive albitization of plagioclase in the mylonites. Evidence for the process of albitization is provided by element maps and EDX-analyses of selected thin sections. Mass losses, particularly the depletion of $\mathrm{Fe}, \mathrm{Mg}$ and $\mathrm{Al}$, are consistent with the observation that clinopyroxene, amphibole and some of the chlorite are decomposed in the mylonitic and ultramylonitic rocks. Interestingly, the mylonites are also depleted in $\mathrm{Ti}$. Ti has been reported as mobile in certain geologic environments [Selverstone et al., 1991], and in the present case Ti mobility is obviously associated with the decomposition of most ferromagnesian minerals during mylonitization. LOI values are distinctly higher in the mylonites than in the cataclasites, reflecting the intense carbonation occurring along with the process of highstrain plastic flow in the MSD. Typically high LOI values are consistent with volume increases recorded for alteration in shear zones [e.g., Dipple and Ferry, 1992; Cartwright and Buick, 1999]. Among the trace elements, $\mathrm{Rb}$ and $\mathrm{Ba}$ behave in the opposite way if compared to cataclastic deformation, showing strong gains in the mylonites. Both elements show strong heterogeneity between samples (vertical bars, Figure $7 b$ ), reflecting variable degrees of syntectonic alteration [see also Grant, 2005]. We interpret these gains as results of fluid infiltration along mineral grain boundaries, causing hydration and hydrolysis reactions that redistribute $\mathrm{Rb}$ and $\mathrm{Ba}$, as well as Sr during mylonitization [Beach and Fyfe, 1972; Beach, 1980].

[31] If the described syntectonic geochemical changes reflect metasomatic interactions of rock and fluid, then the method of Gresens [1967] can be used to derive quantitative mass balance relations between protolith, cataclasite and mylonite. The calculations are based on the average compositions of each rock type, the densities, and on concentration changes of mobile element $n$, as determined from equation (4). Results are expressed as weight percent oxides, rather than mineral percentages. The following two results were calculated for the cataclasites and the mylonites (see also Figure 8). Each result is relative to $100 \mathrm{~g}$ of unaltered protolith:

$$
\begin{aligned}
& 100 \text { g protolith }+0.53 \mathrm{~g} \mathrm{SiO}_{2}-1.27 \mathrm{~g} \mathrm{Al}_{2} \mathrm{O}_{3}+1.68 \mathrm{~g} \mathrm{Fe}_{2} \mathrm{O}_{3} \\
& \quad-0.78 \mathrm{~g} \mathrm{CaO}+2.89 \mathrm{~g} \mathrm{MgO}-0.56 \mathrm{~g} \mathrm{Na}_{2} \mathrm{O}-0.28 \mathrm{~g} \mathrm{~K}_{2} \mathrm{O} \\
& +0.02 \mathrm{~g} \mathrm{MnO}-0.11 \mathrm{~g} \mathrm{TiO}_{2}+0.00 \mathrm{~g} \mathrm{P}_{2} \mathrm{O}_{5}+7.56 \mathrm{~g} \mathrm{LOI} \\
& =109.69 \mathrm{~g} \text { cataclasite }
\end{aligned}
$$

$$
\begin{aligned}
& 100 \text { g protolith }+34.94 \mathrm{~g} \mathrm{SiO}_{2}-5.03 \mathrm{~g} \mathrm{Al}_{2} \mathrm{O}_{3}-5.83 \mathrm{~g} \mathrm{Fe}_{2} \mathrm{O}_{3} \\
& \quad+11.80 \mathrm{~g} \mathrm{CaO}-3.36 \mathrm{~g} \mathrm{MgO}+0.11 \mathrm{~g} \mathrm{Na}_{2} \mathrm{O}+0.32 \mathrm{~g} \mathrm{~K}_{2} \mathrm{O} \\
& \quad+0.05 \mathrm{~g} \mathrm{MnO}-0.85 \mathrm{~g} \mathrm{TiO}_{2}+0.02 \mathrm{~g} \mathrm{P}_{2} \mathrm{O}_{5}+15.92 \mathrm{~g} \mathrm{LOI} \\
& =148.09 \mathrm{~g} \text { mylonite }
\end{aligned}
$$

These equations show that strong silicification and carbonization occurred throughout the MSD primarily during mylonitization, whereas all other major elements show far less gain or loss relative to 


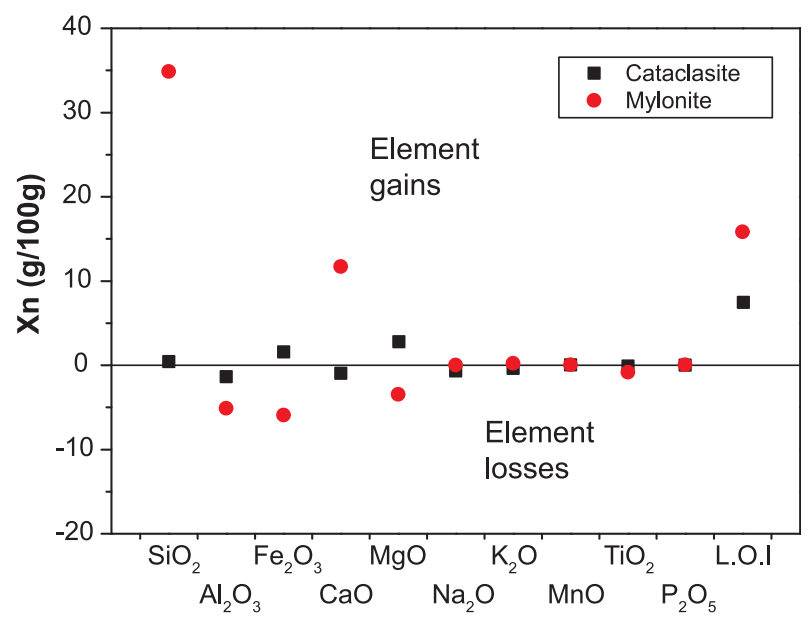

Figure 8. Plot of gains or losses of major elements (in $\mathrm{g}$ per $100 \mathrm{~g}$ ) calculated using equation (4) [Gresens, 1967] to derive quantitative mass balance relations between protolith, cataclasite and mylonite from the Moresby Seamount detachment. See text for discussion.

the protolith (Figure 8). The mass increase occurred mainly through the addition of vein material in stages of brittle deformation. The fact that the mylonites are strongly enriched in silica and calcium carbonate shows that formation of ductile fault rock (the mylonites) from a mafic protolith relies on intermittent brittle fracturing and veining as an important part of the strain accumulating process. Introduction of carbonate and quartz, however, has the effect of weakening the rock and making it more ductile, allowing for quasi-steady plastic flow along the MSD.

\subsection{Isotope Geochemistry}

[32] The ductile part of the MSD represents a shear zone with mass and volume gain. $100 \mathrm{~g}$ of protolith convert to $148 \mathrm{~g}$ of mylonitic fault rock. Generally, shear zones with such gains are characterized by high activity of metamorphic fluids that change chemical and mechanical processes and influence deformation mechanisms [e.g., Sinha et al., 1986; Streit and Cox, 1998].

[33] The mobility of rare earth elements (REE) during hydrothermal fluid-rock interaction has been widely debated in the literature (see Condie and Sinha [1996, and references therein] for details). It seems now accepted that depending on specific hydrothermal environments during deformation and metamorphism, even REE can be mobilized. The mobility of REE during fluid rock interaction is clearly controlled by the nature of the dominant fluid source and the related percolating fluid [Streit and Cox, 1998; Rolland et al., 2003]. Isocon plots of light rare earth elements (LREE) were constructed for the MSD (Figure 9) and show that at least during mylonitization LREE are mobile (Figure 9b). The mobility of LREE itself is a strong argument for vigorous fluid flow along the MSD. But even more importantly, the obvious mobilization of $\mathrm{Nd}$ during mylonite formation opens the possibility to characterize the dominant fluid source using ${ }^{87} \mathrm{Sr} /{ }^{86} \mathrm{Sr}$ and ${ }^{143} \mathrm{Nd} /{ }^{144} \mathrm{Nd}$ isotopic ratios.

[34] Data obtained in this study are presented in Table 2. $\mathrm{Sr}$ and $\mathrm{Nd}$ isotopic ratios of bulk rock samples (see Figure 10) can be subdivided into two isotopic regimes. Protoliths and cataclasites plot between $\varepsilon \mathrm{Nd}=5.1$ and 2.3 and ${ }^{87} \mathrm{Sr} /{ }^{86} \mathrm{Sr}$ ratios of
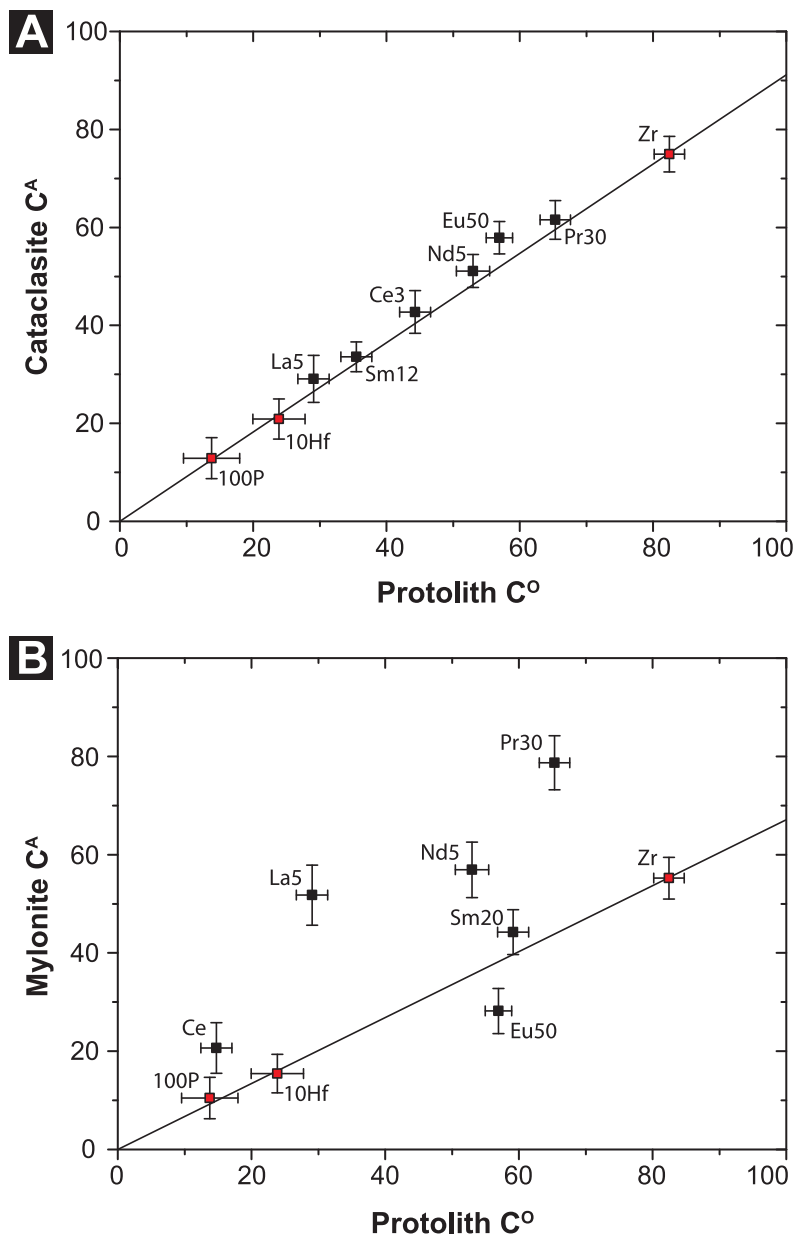

Figure 9. Isocon diagrams of light rare earth elements (LREE). Concentrations $(C)$ are in ppm and scaled to fit on the plot. (a) LREE behave immobile during the process of cataclasis while (b) they are obviously mobilized during mylonitization. The mobility of LREE is a strong argument for intensive fluid flow. See text for discussion. 


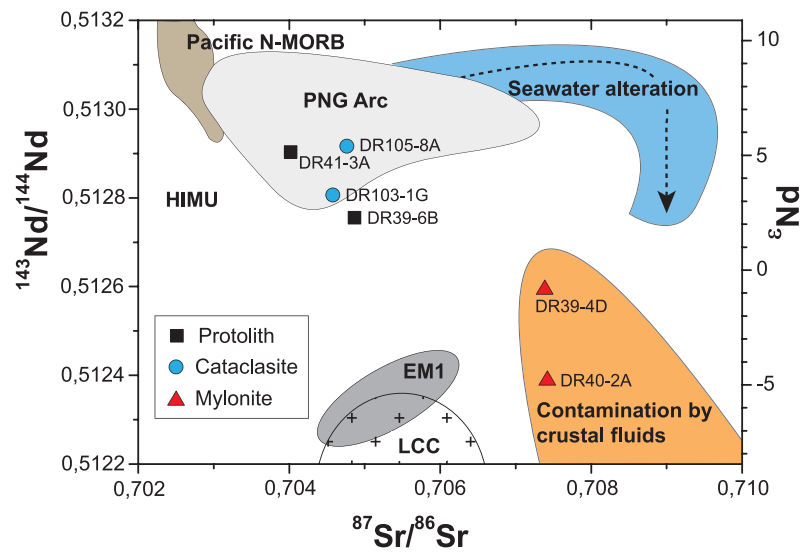

Figure 10. Sr-Nd isotope diagram for different Moresby Seamount detachment rock types, data see Table 2. Data for Papua New Guinea (PNG) Arc compiled from GEOROC database (http://georoc.mpchmainz.gwdg.de), data for Pacific N-MORB compiled from PetDB database (http://www.petdb.org/). Mantle Reservoirs EM1 after Hofmann [2003] and HIMU after Zindler and Hart [1986]. Array for Lower Continental Crust (LCC) after Zartman and Haines [1988]. Seawater alteration and influence of crustal fluid contamination after Schaltegger et al. [2002]. See text for discussion.

about $0.704-0.705$, forming a cluster at the lower limit of Papuan Arc-type $\varepsilon \mathrm{Nd}$ values, illustrating the ophiolitic character of the basement. Metasomatism in cataclasite samples was insufficient to alter their isotopic $\mathrm{Sr}$ and $\mathrm{Nd}$ signature markedly. Data from the mylonite samples, however, show $\varepsilon \mathrm{Nd}$ values in the range of -0.8 and -4.8 as well as a clear rise to higher ${ }^{87} \mathrm{Sr} /{ }^{86} \mathrm{Sr}$ ratios relative to protoliths and cataclasites (see discussion in section 6.3).

\section{Discussion}

\subsection{Relative Timing of Cataclasis, Mylonitization and Chemical Alteration}

[35] The tectono-metamorphic evolution of the MSD is related to the unroofing of the mafic footwall protolith during extensional tectonics under greenschist facies conditions [cf. Taylor et al., 1999]. Each rock-recovery of dredges shown in Figure $2 b$ presents evidence for onset of alteration and deformation of the mafic protolith. Extensive replacement of clinopyroxene \pm hornblende + plagioclase by an alteration assemblage along the MSD are documented by the results of this study. Such alteration requires influx of externally derived fluid prior or during brittle and plastic deformation (see discussion in sections 6.2 and 6.3). Extensional faulting on Moresby Seamount was initiated by cataclasis (Figures 4 and 5). Fracture connectivity due to fault rupture permits fluid infiltration, and allows grain-size reduction processes to operate. Cataclastic hardening results in broadening of the evolving shear zone, and utilization of other preexisting joints and with ongoing deformation. As the volume of permeable cataclasite and the reactive fracture surface in the MSD increases, enhanced metasomatism leads to intense chloritization (Figures $4 \mathrm{c}$ and $4 \mathrm{~d}$ ). The development of S-C fabrics in chlorite-dominated cataclasites/phyllonites emphasizes the role of chemical alteration in affecting the MSD fault zone rheology, forming cohesive cataclasites with the observed foliated fabrics. Foliation-parallel hydrofractures (Figure 4d) with crack-seal structures [Ramsay, 1980], and more complex vein networks (Figure 4c) then enable massive syntectonic infiltration of quartz and calcite (Figure 6), and loss of clinopyroxene and plagioclase within the fault rocks. The enrichment of rheologically weak quartz and calcite then causes a transition from cataclastic to plastic flow, and fault localization (see discussion in sections 6.3 and 6.4). Evidence for this is that the cataclasites studied never contain recycled mylonitic clasts. Thus, intense brittle overprinting of plastic fault rocks while the footwall was cooling through the brittleplastic transition was likely insignificant, or localized in discrete zones of slip. However, crosscutting calcite veins in the mylonites (Figure $5 \mathrm{~g}$ ) indicate that plastic deformation was interrupted by episodic stress build-up and fracture, and these veins are interpreted as syntectonic with respect to the MSD faulting. In summary, protoliths and fault rocks of the MSD record spatial and temporal overlaps of fluid infiltration, brittle deformation and plastic deformation, with most of the metasomatic changes related to mylonite formation and operation.

\subsection{Fluid Flux During MSD Evolution}

[36] The time-integrated fluid flux [Dipple and Ferry, 1992] couples fluid flow and chemical reactions, thus providing a way to interpret geochemical data in terms of fluid sources and flux. Fluid flux can be derived from the change of concentration of elements, their solubilities, and the geothermal gradient [e.g., Ferry and Dipple, 1991]. In doing so, changes in elemental abundances are used to calculate the volumes of fluids bringing about the metasomatic change observed. In large advection dominated fluid flow systems [Bickle 

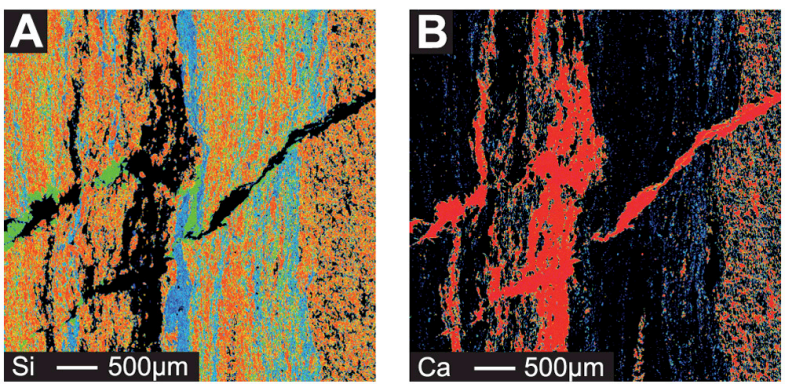

Figure 11. Element maps of (a) $\mathrm{Si}$ and (b) $\mathrm{Ca}$ of the mylonite sample DR41-1B (foliation is running vertical) showing the characteristic crosscutting relationships of veins and their infills in Moresby Seamount detachment (MSD) fault rocks. In Figure 11a, orange and reddish colors are quartz, greenish and bluish colors are albite. In Figure 11b, reddish colors are calcite. Figures 11a and $11 \mathrm{~b}$ document the evolution of hydrothermal fluids from silicia-rich to calcite-rich composition during deformation and exhumation of the MSD.

and Mckenzie, 1987] where fluid-rock equilibrium can be assumed and dispersion ignored, the timeintegrated fluid flux is given by:

$$
q=\frac{n_{i}}{\left(\partial X_{i} / \partial T\right)_{p}(d T / d z)+\left(\partial X_{i} / \partial P\right)_{T}(d P / d z)}
$$

[Dipple and Ferry, 1992], where $n_{i}$ is the change in concentration of element $i$ during metasomatism, $\left(\partial X_{i} / \partial T\right)_{p}$ and $\left(\partial X_{i} / \partial P\right)_{T}$ are the temperature and pressure dependencies of the solubility of element $i$, and $(d T / d z)$ and $(d P / d z)$ are the temperature and pressure gradients along the fluid-flow path, respectively.

[37] Along the MSD, fault rocks that underwent mylonitization experienced increases of $\mathrm{Si}$, which we determine from mass balance equation (6) to be equal to $34.94 \mathrm{~g} \times 100 \mathrm{~g}^{-1}$ (Figure 8), or, using the measured densities, $17736 \mathrm{~mol} \mathrm{Si} \mathrm{m}^{-3}$. For temperatures in the MSD of $300-350^{\circ} \mathrm{C}$ and pressures of ca. $200 \mathrm{MPa}$ [cf. Famin and Nakashima, 2005] $\left(\partial X_{i} / \partial T\right)_{p}$ is estimated at $1 \times 10^{-5} \mathrm{~mol}^{\circ} \mathrm{C}^{-1}$ [Fournier and Potter, 1982]. The second term in the denominator of equation (7) is much less significant and may be discounted when calculating fluid fluxes [cf. Dipple and Ferry, 1992]. At the onset of detachment operation the temperature gradient within the fault zone is assumed to be $30^{\circ} \mathrm{C} \mathrm{km}^{-1}$ as suggested by ODP Leg 180 heat flow data from boreholes away from the fault system [Taylor et al., 1999]. After detachment operation and crustal thinning had started, the synrift geotherm evolved toward the present-day values of about $100^{\circ} \mathrm{C} \mathrm{km}^{-1}$ [Taylor et al., 1999]. This is a large difference. In practice, however, the temperature gradient is one of the least sensitive parameters in the calculations. We here use values of $30^{\circ} \mathrm{C} \mathrm{km}^{-1}$ and $100^{\circ} \mathrm{C} \mathrm{km}^{-1}$ to provide calculations for end-member situations, and this range is taken to reflect a reasonable estimate of the time-integrated fluid flux through the MSD. Using both geothermal gradients, time-integrated fluid flux is estimated to range between $1.77 \times 10^{10}$ and $5.91 \times 10^{10} \mathrm{~mol}$ $\mathrm{m}^{-2}$, for geothermal gradients of $100^{\circ} \mathrm{C} \mathrm{km}^{-1}$ and $30^{\circ} \mathrm{C} \mathrm{km}^{-1}$ respectively. This translates to volumes of about $3.19 \times 10^{5} \mathrm{~m}^{3} \mathrm{~m}^{-2}$ related to a $100^{\circ} \mathrm{C}$ $\mathrm{km}^{-1}$ geotherm, and $1.06 \times 10^{6} \mathrm{~m}^{3} \mathrm{~m}^{-2}$ with reference to the $30^{\circ} \mathrm{C} \mathrm{km}^{-1}$ geotherm at the onset of rifting. Fluid flow in the MSD is presumed to be upward and updip. Quartz solubility has been documented to increase with increasing temperature; hence the observed $\mathrm{SiO}_{2}$-precipitation in the MSD is evidence for down-temperature (i.e., upward) fluid flow [McCaig, 1997].

[38] Fluid fluxes of the calculated magnitude are consistent with extreme metasomatism, fall within the range of values in the literature generally estimated for shear zones (typically $10^{5}-10^{6} \mathrm{~m}^{3} \mathrm{~m}^{-2}$ ) [e.g., Selverstone et al., 1991; Dipple and Ferry, 1992; McCaig, 1997; Streit and Cox, 1998; Cartwright and Buick, 1999], and imply migration of substantial quantities of externally derived fluid through the zone of deformation.

\subsection{Fluid Source}

[39] Extensional detachment faulting is often accompanied by strong hydrothermal alteration. However, the source of fluids has been shown to vary [Fricke et al., 1992; Wickham et al., 1993; Famin and Nakashima, 2005], being either dominantly surface derived or dominantly metamorphic. The crosscutting relationships of veins and their infills in fault rocks of the MSD (Figure 11) show that the compositions of hydrothermal fluids evolved from silica-rich to calcite-rich during deformation and exhumation. According to Famin and Nakashima [2005], salinities of fluid inclusions related to the chronologically early stage of faulting in the MSD are higher than those of more recently trapped fluid inclusions at shallow depths. Such trends typically indicate a metamorphic fluid source [Miller et al., 2002]. Submissive mixing of metamorphic fluids with surface derived fluids, probably in the younger exhumation stage, could then explain the low salinity of the more recent fluid inclusions and the shift of the vein infills from silica-rich to calcite-rich (Figure 11) [Famin and Nakashima, 2005]. 


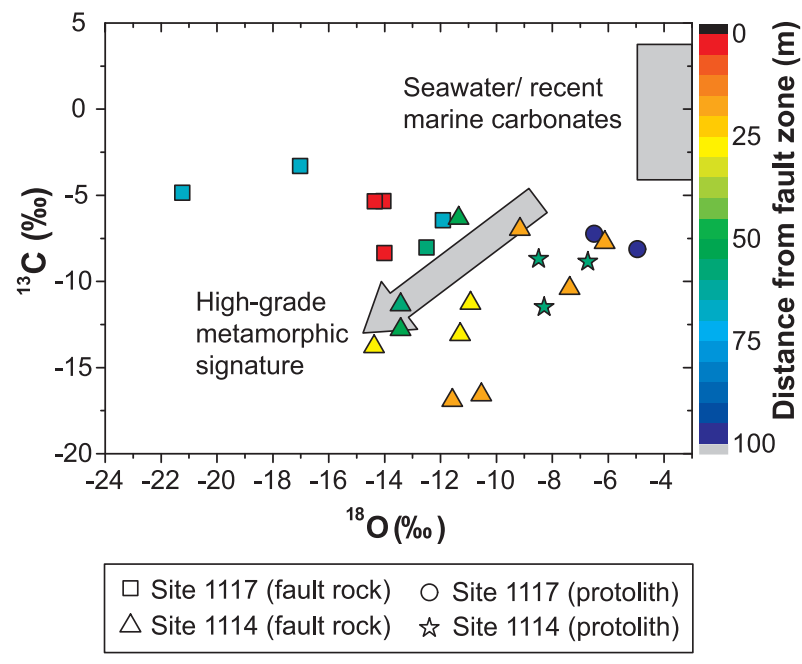

Figure 12. $\mathrm{C}$ and $\mathrm{O}$ stable isotopes diagram (modified after Kopf et al. [2003], copyright 2003, with permission from Elsevier) of carbonate vein infills from rocks of the Moresby Seamount detachment (ODP drillsite 1117) and one antithetic normal fault (ODP drillsite 1114). Note the trend toward a high grade metamorphic signature, indicating a dominant crustal fluid source. See text for discussion.

[40] Our Sr and Nd isotope data (Figure 10) show a shift of the $\mathrm{Nd}$ isotopic ratios to lower values as well as a clear rise to higher ${ }^{87} \mathrm{Sr} /{ }^{86} \mathrm{Sr}$ ratios for the mylonitic samples. The strongly increasing $\mathrm{Sr}$ isotopic ratios of the mylonites appear to indicate seawater alteration. However, seawater alteration would occur at near constant $\mathrm{Nd}$ isotopic compositions [Schaltegger et al., 2002]. We propose that the high ${ }^{87} \mathrm{Sr} /{ }^{86} \mathrm{Sr}$ ratios and the lower $\mathrm{Nd}$ isotopic ratios are better explained by crustal contamination, and we interpret this shift as being caused by circulation of metamorphic fluids from the lower crust during detachment activity. The MSD experiences a down-temperature flow from depth, resulting from dehydration and decarbonation of metamorphic lower crust. We also interpret negative $\delta^{13} \mathrm{C}$ and $\delta^{18} \mathrm{O}$ isotopic ratios in Figure 12 [cf. Kopf et al., 2003] to result from metamorphic fluids released at depth. All shown $\mathrm{C}$ and $\mathrm{O}$ isotope signatures are from fault rock calcite vein cements of ODP Leg 180 cores [Kopf et al., 2003]. Further away from fault zones the protolithic rocks, mainly gabbros, show the highest $\delta^{18} \mathrm{O}$ ratios (Figure 12), which suggests that fluid flow was less efficient with increasing distance from the fault zones [Kopf et al., 2003].

[41] We interpret all data and observations described above as reflecting a dominant crustal fluid source. As argued below the ingress of metamorphic fluids strongly influences the deformation mechanisms in the ductile MSD mylonites. Fluid inclusions in vein infills of the MSD fault rocks [Famin and Nakashima, 2005] suggest a circulation of surface-derived fluids that penetrate only a short distance along the MSD, where they mix with upward moving metamorphic fluids. Mixing of both fluid types is quite common in extensional tectonic settings [McCaig, 1997], and the MSD provides further evidence for this type of fluid signature.

\subsection{How Important Is Metasomatism for Fault Zone Weakening?}

[42] Many experimental studies indicate that continental lithosphere is too strong to be parted by plate tectonic forces, if brittle rupture with a stress according to Byerlee's Law is to occur in typical crustal rocks. Yet geological evidence suggests that detachment faults in rifts are weak and can thus operate under low differential stresses. Explanations for fault weakness include the presence of a weak mineral assemblage [e.g., Shimamoto and Logan, 1981; Chester and Logan, 1986; Rutter et al., 1986; Moore and Rymer, 2007] and/or high fluid pressures within the fault core [e.g., Blanpied et al., 1992; Rice, 1992]. Weak phyllosilicates (e.g., smectite, chlorite and talc) are important in localizing shear and focusing fluid flow along detachments faults [e.g., Boschi et al., 2006; Niemeijer and Spiers, 2006]. Brittle fault rocks along the MSD contain abundant chlorite, which cannot be explained by isochemical reactions within the mafic host rock. The occurrence of these phyllosilicates is restricted to Mg-rich rocks [e.g., Moore and Lockner, 2008], and a typical example may be the metamorphosed mafic rocks of the ophiolites that seem to form Moresby Seamount. The development of phyllosilicate-foliation networks has been identified as a major fault zone weakening mechanism [Evans and Chester, 1995; Vrolijk and Van der Pluijm, 1999; Bos et al., 2000; Jefferies et al., 2006]. Cleavage-parallel slip in interconnected chlorite layers of the MSD phyllonites (Figure 4d) is a likely result of such a weakening process. Simple hydration of pyroxenes during deformation and retrograde metamorphism yields talc and chlorite [Moore and Lockner, 2008], however, an extra source of $\mathrm{Si}$ is required for this process. Our mass transfer calculations (Figure 8 and equations (5) and (6)) for the MSD demonstrate that Si-saturated hydrothermal fluids provided the additional $\mathrm{Si}$ needed for weak phyllosilicates to crystallize from e.g., pyroxene. Thus in the MSD, one major fault zone weakening process is the metasomatic replacement of 


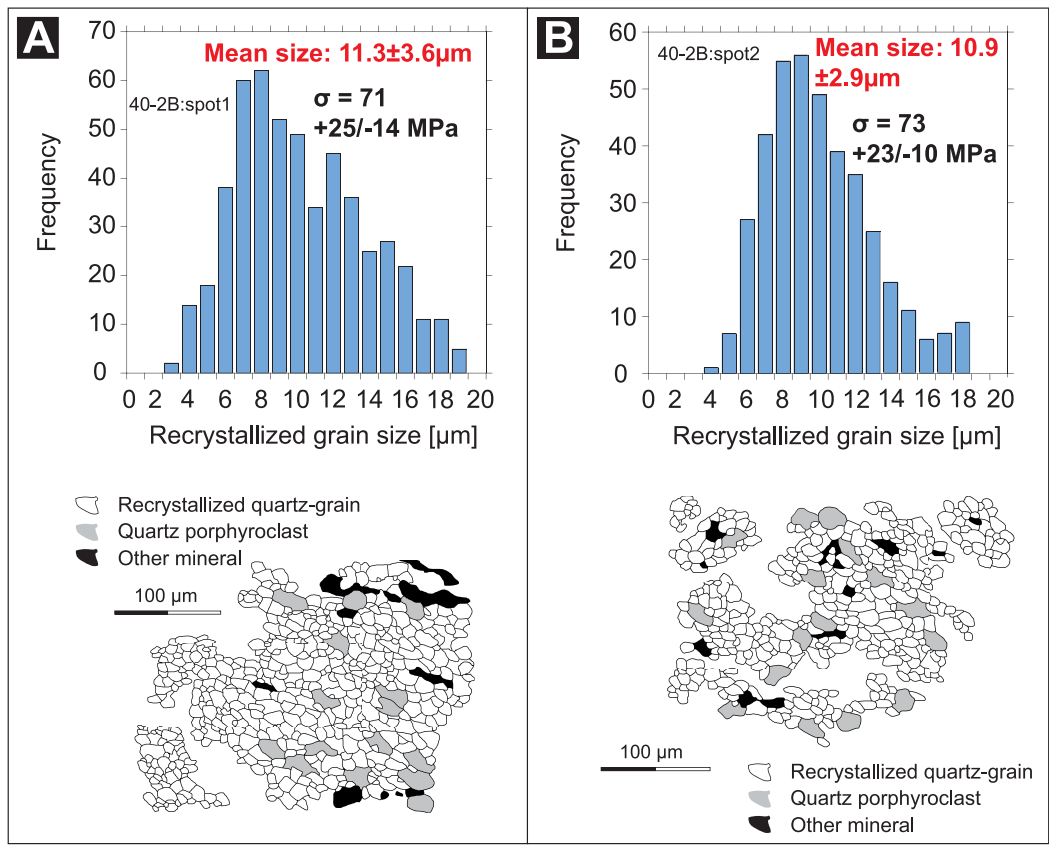

Figure 13. Characteristic quartz microstructure that represents the maximum flow stress of the Moresby Seamount detachment [Speckbacher et al., 2011]. (a and b) Grain boundary maps and related 2D-recrystallized grain size distributions of quartz from two areas of sample DR40-2B. Recrystallized grains were distinguished from porphyroclasts based on microstructural evidence. The mean recrystallized grain size of $11.3 \pm 3.6 \mu \mathrm{m}$ and $10.9 \pm 2.9 \mu \mathrm{m}$ corresponds to a flow stress $(\sigma)$ of $71+25 /-14 \mathrm{MPa}$ and $73+23 /-10 \mathrm{MPa}$, respectively, when applying the experimental piezometer of Stipp and Tullis [2003].

strong mafic minerals by weak phyllosilicates, mainly chlorite.

[43] In a regime of vigorous fluid flow in the MSD, fluid overpressure may also be a weakening mechanism. The bottom water anomalies identified by our AUV survey above the lowermost part of the detachment surface (see Speckbacher et al. [2011] for details) indicate that the MSD is still an active conduit for fluids. Multiple vein generations in the cataclasites (Figure 4c) indicate a history of high fluid pressures for the whole period of formation and operation of the MSD, and foliation-parallel hydrofractures with crack-seal textures (Figure 4d) give evidence of their syntectonic cycling.

[44] While high fluid pressures and the presence of weak minerals, such as phyllosilicates, assist in creating and maintaining low strength in the brittle regime, other processes must be in operation to create the ductile mylonites exhumed today at the seafloor. These are reminiscent of plastic flow at greater depth. The key requirement to create mylonites from a fractured mafic protolith is the relative enrichment of minerals capable to deform in a plastic manner at relatively low temperatures, like calcite or quartz. The mass balance calculations given above show that mylonitization leads to an average enrichment of Si (34.94 g) and Ca (11.80 g) (with respect to $100 \mathrm{~g}$ of protolith, see also Figure 8). This syntectonic enrichment brings about a major change in mineralogy of the fault rocks, enabling the fault rocks to deform plastically above syntectonic temperatures of $220^{\circ} \mathrm{C}$ (calcite) [cf. Herwegh and Pfiffner, 2005] or $280 \pm 30^{\circ} \mathrm{C}$ (quartz) [cf. Stipp et al., 2002]. The fresh protolith, rich in plagioclase and clinopyroxene, will likely remain brittle up to at least $450^{\circ} \mathrm{C}$. The metasomatic addition of sufficient calcite (Figure 6) and quartz allows the MSD mylonites to creep plastically at very low differential stress [cf. Speckbacher et al., 2011]. In the quartz microstructure of MSD mylonites (Figure 13) any evidence for very low temperature bulging recrystallization, the key indicator for a brittle-plastic transition at high stresses (BLG I of Stipp et al. [2002]), is lacking. Considering a normal geothermal gradient of $30^{\circ} \mathrm{C} \mathrm{km}^{-1}$, the crustal level where mylonitization occurs is below $10 \mathrm{~km}$ depth at $250-350^{\circ} \mathrm{C}$. This may have been the case before mylonitization started in the MSD. Later, crustal attenuation led to an increase to about $100^{\circ} \mathrm{C} \mathrm{km}^{-1}$ [Taylor and Huchon, 2002]. Hence, during later operation of the MSD, Moresby Seamount represents the case of a brittle- 
plastic transition and plastic flow at much shallower crustal levels (about $3 \mathrm{~km}$ depth).

\subsection{How Can a Fault Be Weak but Generate Earthquakes?}

[45] From the evidence above it can be inferred that the MSD tends to act as a weak fault, with a rheology being capable to creep steadily. Yet the lowangle $\left(\sim 30^{\circ}\right) \mathrm{MSD}$ is known to generate large (Mw 6.2) earthquakes [Abers et al., 1997], a proof that the fault is not constantly creeping. The coexistence of relatively low stress mylonites at lower depth and seismic deformation down to greater depth reflects an extraordinary rheological situation caused by the very high geothermal gradient as well as the quartz and calcite-veining at Moresby Seamount [Speckbacher et al., 2011]. However, this may have been more common in fossil low-angle detachment faults worldwide. The low overburden to such fault systems excludes high differential stresses. In lower greenschist facies quartz-bearing rocks, the brittle-plastic transition occurs at a temperature of $\sim 280^{\circ} \mathrm{C}$ (see discussion in section 6.4). Expected dynamically recrystallized grain sizes would be $<5 \mu \mathrm{m}$, indicating a differential stress of 200-250 MPa, when applying the piezometer of Stipp and Tullis [2003] and the Griggs rig correction of Holyoke and Kronenberg [2010]. These are differential stresses way above what is possible in the MSD covered by, say, three kilometers of overburden. The smallest recrystallized grain sizes observed in quartz from the MSD (Figure 13), however, are always $>10 \mu \mathrm{m}$, relating to a differential stress of $\sim 70 \mathrm{MPa}$ or less [Speckbacher et al., 2011]. Extraordinary high water concentrations, which can be assumed for the MSD at the calculated high fluid fluxes, weaken the quartz [Griggs and Blacic, 1965] but do not affect the piezometric relationship of quartz [Stipp et al., 2006]. This is about the maximum differential stress that can be supported in the MSD and its maximum $3 \mathrm{~km}$ overburden without prompting tensile failure. Hence, these differential stresses are characteristic of the brittle-plastic transition in the fault rocks, as demonstrated by the presence of deformation microstructures indicative of both, brittle fracture and plastic flow. The brittleplastic transition at such low differential stresses is supposed to be related to very low confining pressures, as predicted by Goetze's criterion [e.g., Kohlstedt et al., 1995], in which differential stress cannot be higher than the confining pressure to assure plastic deformation. In this situation changes in the effective confining pressure are likely controlled by local short-lived build-ups of high fluid pressure. Fluid pressure modulations allow for repeated switches from plastic to brittle behavior. Hence, this particular fault zone behavior may play an important role in triggering seismicity on the MSD, and explains why earthquake-generating instabilities [Scholz, 1998] (microearthquakes described by Ferris et al. [2006]) may occur above temperatures usually associated with the brittleplastic transition of quartz and calcite mylonites.

\section{Conclusion}

[46] We propose an important genetic link between fracturing, fluid flow, metasomatism, crustal weakening, and the development of the MSD. The release and channeling of crust-derived fluids appears to be a mechanism for the localization and long-lasting operation of the MSD. Our conclusion is that fluid-assisted metasomatic changes in the MSD are instrumental in creating and maintaining the MSD as a crustal-scale weak extensional detachment fault. The changes are sufficiently large to turn an initially strong and brittle mafic protolith into ductile mylonites capable of sustaining plastic flow at low differential stresses. Episodic high fluid pressures, another characteristic of the MSD, allow for repeated mechanism switches of brittle and plastic deformation and help to sustain the hydrothermal discharge of deep crustal fluids until the present-day. This behavior also explains why the MSD is capable of producing earthquakes [Abers et al., 1997], despite its general structural definition as a ductile shear zone in earthquake relevant depths. From the quantification of the metasomatic changes, the estimated minimum time integrated fluid flux is at least $3 \times 10^{5} \mathrm{~m}^{3} \mathrm{~m}^{-2}$. This means that the MSD is an important crustal fluid conduit, operating over a million year timescale until today. The substantial $\mathrm{Si}$ and $\mathrm{Ca}$ gains as well as conclusive $\mathrm{Sr}$ and $\mathrm{Nd}$ isotope data provide clear arguments for upward fluid flow from a deeper crustal source, driving metasomatic change during deformation. There is some volume gain related to brittle deformation and cataclasis, but the more significant changes and volume gains are clearly related to the process of ductile mylonite generation.

[47] Fundamental syntectonic mineralogical changes from the mafic protolith lead to fault zone weakening. For one, this is the formation of phyllosilicates from pyroxene and plagioclase during brittle shearing, but it is metasomatic introduction of large amounts of quartz and calcite that helps create the ductile mylonites and stabilize the MSD 
as a detachment zone. This process leads to largescale strain concentration, may be the key factor in localizing crustal attenuation and later crustal break-up, and may be a general process active in passive continental margin formation.

\section{Acknowledgments}

[48] The authors gratefully acknowledge constructive comments by D. E. Moore, an anonymous reviewer, as well as editing by G. L. Früh-Green and T. Becker, which helped us to improve the paper significantly. Analytical help by S. Petersen and F. Hauff is much appreciated. We thank the Master, personnel of R/V Sonne and the AUV-Team for their competent work in supporting the mapping and sampling mission at Moresby Seamount. This work was financially supported by Bundesministerium für Bildung und Forschung grant 03G0203A.

\section{References}

Abers, G. A., C. Z. Mutter, and J. Fang (1997), Shallow dips of normal faults during rapid extension: Earthquakes in the Woodlark-D'Entrecasteaux rift system, Papua New Guinea, J. Geophys. Res., 102(B7), 15,301-15,317, doi:10.1029/ 97JB00787.

Akella, J. (1966), Calculation of material transport in some metasomatic processes, Neues Jahrb. Mineral Abh., 104, 316-329.

Axen, G. J. (1999), Low-angle normal fault earthquakes and triggering, Geophys. Res. Lett., 26(24), 3693-3696, doi:10.1029/1999GL005405.

Axen, G. J. (2004), Mechanics of low-angle normal faults, in Rheology and Deformation in the Lithosphere at Continental Margins, edited by G. Karner et al., pp. 46-91, Columbia Univ. Press, New York.

Axen, G. J., and J. Selverstone (1994), Stress state and fluidpressure level along the Whipple detachment fault, Calif. Geol., 22(9), 835-838.

Baldwin, S. L., G. S. Lister, E. J. Hill, D. A. Foster, and I. Mcdougall (1993), Thermochronological constraints on the tectonic evolution of active metamorphic core complexes, Dentrecasteaux Islands, Papua-New-Guinea, Tectonics, 12(3), 611-628, doi:10.1029/93TC00235.

Baldwin, S. L., B. D. Monteleone, L. E. Webb, P. G. Fitzgerald, M. Grove, and E. J. Hill (2004), Pliocene eclogite exhumation at plate tectonic rates in eastern Papua New Guinea, Nature, 431(7006), 263-267, doi:10.1038/nature02846.

Baldwin, S. L., T. R. Ireland, P. G. Fitzgerald, and L. E. Webb (2012), Tectonics of the New Guinea region, Annu. Rev. Earth Planet. Sci., 40, 495-520, doi:10.1146/annurev-earth040809-152540.

Barnicoat, A. C., and S. A. Bowtell (1995), Sea-floor hydrothermal alteration in metabasites from high-pressure ophiolites of the Zermatt-Aosta area of the western Alps, Boll. Mus. Reg. Sci. Nat. Torino, 13, 191-220.

Baumgartner, L. P., and S. N. Olsen (1995), A least-squares approach to mass-transport calculations using the isocon method, Econ. Geol., 90(5), 1261-1270, doi:10.2113/ gsecongeo.90.5.1261.
Beach, A. (1980), Retrogressive metamorphic processes in shear zones with special reference to the Lewisian Complex, J. Struct. Geol., 2(1-2), 257-263, doi:10.1016/0191-8141(80) 90058-9.

Beach, A., and W. S. Fyfe (1972), Fluid transport and shear zones at Scourie, Sutherland: Evidence of overthrusting?, Contrib. Mineral. Petrol., 36(3), 175-180, doi:10.1007/ BF00371429.

Behrmann, J. H. (1988), Crustal-scale extension in a convergent orogen: The Sterzing-Steinach mylonite zone in the eastern Alps, Geodin. Acta, 2(2), 63-73.

Bickle, M. J., and D. Mckenzie (1987), The transport of heat and matter by fluids during metamorphism, Contrib. Mineral. Petrol., 95(3), 384-392, doi:10.1007/BF00371852.

Blanpied, M. L., D. A. Lockner, and J. D. Byerlee (1992), An earthquake mechanism based on rapid sealing of faults, Nature, 358, 574-576, doi:10.1038/358574a0.

Bos, B., C. J. Peach, and C. J. Spiers (2000), Slip behavior of simulated gouge-bearing faults under conditions favoring pressure solution, J. Geophys. Res., 105(B7), 16,699-16,717, doi:10.1029/2000JB900089.

Boschi, C., G. L. Fruh-Green, and J. Escartin (2006), Occurrence and significance of serpentinite-hosted, talc- and amphibole-rich fault rocks in modern oceanic settings and ophiolite complexes: An overview, Ofioliti, 31(2), 129-140.

Brooks, K., and C. Tegner (2001), Affinity of the Leg 180 dolerites of the Woodlark Basin: Geochemistry and age, Proc. Ocean Drill. Program Sci. Results, 180, 1-18.

Burchfiel, B. C., C. Zhiliang, K. V. Hodges, L. Yuping, L. H. Royden, D. Changrong, and X. Jiene (1992), The south Tibetan detachment system, Himalayan orogen: Extension contemporaneous with and parallel to shortening in a collisional mountain belt, Spec. Pap. Geol. Soc. Am., 269, 41 pp.

Byerlee, J. (1978), Friction of rocks, Pure Appl. Geophys., 116(4-5), 615-626, doi:10.1007/BF00876528.

Cartwright, I., and A. C. Barnicoat (2003), Geochemical and stable isotope resetting in shear zones from Taschalp: Constraints on fluid flow during exhumation in the western Alps, J. Metamorph. Geol., 21(2), 143-161, doi:10.1046/j.15251314.2003.00423.x.

Cartwright, I., and I. S. Buick (1999), The flow of surface-derived fluids through Alice Springs age middle-crustal ductile shear zones, Reynolds Range, central Australia, J. Metamorph. Geol., 17(4), 397-414, doi:10.1046/j.1525-1314.1999.00205.x.

Chester, F. M., and J. M. Logan (1986), Implications for mechanical properties of brittle faults from observations of the Punchbowl Fault Zone, California, Pure Appl. Geophys., 124, 79-106, doi:10.1007/BF00875720.

Clark, C., A. S. Mumm, and K. Faure (2005), Timing and nature of fluid flow and alteration during Mesoproterozoic shear zone formation, Olary Domain, South Australia, J. Metamorph. Geol., 23(3), 147-164, doi:10.1111/j.15251314.2005.00568.x.

Collettini, C. (2011), The mechanical paradox of low-angle normal faults: Current understanding and open questions, Tectonophysics, 510(3-4), 253-268, doi:10.1016/j.tecto.2011. 07.015 .

Condie, K. C., and A. K. Sinha (1996), Rare earth and other trace element mobility during mylonitization: A comparison of the Brevard and Hope Valley shear zones in the Appalachian Mountains, USA, J. Metamorph. Geol., 14(2), 213-226, doi:10.1046/j.1525-1314.1996.05899.x.

Davies, H. L. (1971), Peridotite-gabbro-basalt complex in eastern Papua: An overthrust plate of oceanic mantle and crust, Bull. Aust. Bur. Miner. Resour. Geol. Geophys., 128, 48 pp. 
Davies, H. L., and A. L. Jaques (1984), Emplacement of ophiolite in Papua New Guinea, in Ophiolites and Oceanic Lithosphere, edited by I. G. Gass, S. J. Lippard, and A. W. Shelton, Geol. Soc. Spec. Publ., 13, 341-350.

Davies, H. L., and R. G. Warren (1988), Origin of eclogitebearing, domed, layered metamorphic complexes (core complexes) in the Dentrecasteaux Islands, Papua-New-Guinea, Tectonics, 7(1), 1-21, doi:10.1029/TC007i001p00001.

Demény, A., Z. D. Sharp, and H.-R. Pfeifer (1997), Mgmetasomatism and formation conditions of $\mathrm{Mg}$-chloritemuscovite-quartzphyllites (leucophyllites) of the eastern Alps (W. Hungary) and their relations to Alpine whiteschists, Contrib. Mineral. Petrol., 128, 247-260, doi:10.1007/ s004100050306.

Devey, C. (Ed.) (2009), FS Sonne Fahrtbericht/Cruise Report SO203: WOODLARK: Magma Genesis, Tectonics and Hydrothermalism in the Woodlark Basin, Townsville, AustraliaAuckland, New Zealand, 177 pp., GEOMAR, Helmholtz Cent. for Ocean Res. Kiel, Kiel, Germany.

Dipple, G. M., and J. M. Ferry (1992), Metasomatism and fluid-flow in ductile fault zones, Contrib. Mineral. Petrol., 112(2-3), 149-164, doi:10.1007/BF00310451.

Evans, J. P., and F. M. Chester (1995), Fluid rock interaction in faults of the San Andreas system: Inferences from San Gabriel fault-rock geochemistry and microstructures, J. Geophys. Res., 100, 13,007-13,020, doi:10.1029/94JB02625.

Famin, V., and S. Nakashima (2005), Hydrothermal fluid venting along a seismogenic detachment fault in the Moresby rift (Woodlark basin, Papua New Guinea), Geochem. Geophys. Geosyst., 6, Q12003, doi:10.1029/2005GC001112.

Ferris, A., G. A. Abers, B. Zelt, B. Taylor, and S. Roecker (2006), Crustal structure across the transition from rifting to spreading: The Woodlark rift system of Papua New Guinea, Geophys. J. Int., 166(2), 622-634, doi:10.1111/j.1365-246X. 2006.02970.x.

Ferry, J. M., and G. M. Dipple (1991), Fluid-flow, mineral reactions, and metasomatism, Geology, 19(3), 211-214, doi:10.1130/0091-7613(1991)019<0211:FFMRAM>2.3.CO;2.

Floyd, J. S., J. C. Mutter, A. M. Goodliffe, and B. Taylor (2001), Evidence for fault weakness and fluid flow within an active low angle normal fault, Nature, 411, 779-783, doi: $10.1038 / 35081040$.

Fournier, R. O., and R. W. Potter (1982), An equation correlating the solubility of quartz in water from $25^{\circ} \mathrm{C}$ to $900^{\circ} \mathrm{C}$ at pressures up to 10,000 bars, Geochim. Cosmochim. Acta, 46(10), 1969-1973, doi:10.1016/0016-7037(82)90135-1.

Fricke, H. C., S. M. Wickham, and J. R. Oneil (1992), Oxygen and hydrogen isotope evidence for meteoric water infiltration during mylonitization and uplift in the Ruby Mountains-East Humboldt Range Core Complex, Nevada, Contrib. Mineral. Petrol., 111(2), 203-221, doi:10.1007/BF00348952.

Froitzheim, N., and G. P. Eberli (1990), Extensional detachment faulting in the evolution of a Tethys passive continentalmargin, eastern Alps, Switzerland, Geol. Soc. Am. Bull., 102, 1297-1308, doi:10.1130/0016-7606(1990)102<1297: EDFITE $>2.3 . \mathrm{CO} ; 2$.

Garcés, M., and J. S. Gee (2007), Paleomagnetic evidence of large footwall rotations associated with low-angle faults at the Mid-Atlantic Ridge, Geology, 35(3), 279-282, doi:10.1130/ G23165A.1.

Goodliffe, A. M., and B. Taylor (2007), The boundary between continental rifting and seafloor spreading in the Woodlark Basin, Papua New Guinea, in Imaging, Mapping and Modelling Continental Lithosphere Extension and Breakup, edited by G. D. Karner, G. Manatschal, and L. M. Pinhiero, Geol. Soc. Spec. Publ., 282, 213-234.

Goodliffe, A. M., B. Taylor, F. Martinez, R. Hey, K. Maeda, and K. Ohno (1997), Synchronous reorientation of the Woodlark Basin spreading center, Earth Planet. Sci. Lett., 146(1-2), 233-242, doi:10.1016/S0012-821X(96)00227-0.

Grant, J. A. (1986), The isocon diagram-A simple solution to Gresens equation for metasomatic alteration, Econ. Geol., 81(8), 1976-1982, doi:10.2113/gsecongeo.81.8.1976.

Grant, J. A. (2005), Isocon analysis: A brief review of the method and applications, Phys. Chem. Earth, 30(17-18), 997-1004.

Gresens, R. L. (1967), Composition-volume relationships of metasomatism, Chem. Geol., 2, 47-65, doi:10.1016/00092541(67)90004-6.

Griggs, D. T., and J. D. Blacic (1965), Quartz-Anomalous weakness of synthetic crystals, Science, 147(3655), 292-295, doi:10.1126/science.147.3655.292.

Gueydan, F., Y. M. Leroy, L. Jolivet, and P. Agard (2003), Analysis of continental midcrustal strain localization induced by microfracturing and reaction-softening, J. Geophys. Res., 108(B2), 2064, doi:10.1029/2001JB000611.

Herwegh, M., and O. A. Pfiffner (2005), Tectono-metamorphic evolution of a nappe stack: A case study of the Swiss Alps, Tectonophysics, 404(1-2), 55-76, doi:10.1016/j.tecto.2005. 05.002.

Hill, E. J., S. L. Baldwin, and G. S. Lister (1992), Unroofing of active metamorphic core complexes in the Dentrecasteaux Islands, Papua-New-Guinea, Geology, 20(10), 907-910, doi:10.1130/0091-7613(1992)020<0907:UOAMCC $>2.3 . C O ; 2$.

Hoernle, K. A., and G. R. Tilton (1991), Sr-Nd-Pb isotope data for Fuerteventura (Canary Islands) basal complex and subaerial volcanics: Applications to magma genesis and evolution, Schweiz. Mineral. Petrogr. Mitt., 71, 3-18.

Hoernle, K., et al. (2008), Arc-parallel flow in the mantle wedge beneath Costa Rica and Nicaragua, Nature, 451(7182), 1094-1097, doi:10.1038/nature06550.

Hofmann, A. W. (2003), Sampling mantle heterogeneity through oceanic basalts: Isotopes and trace elements, in Treatise on Geochemistry, vol. 2, The Mantle and Core, edited by $\mathrm{H}$. Holland and K. K. Turekian, pp. 61-101, Elsevier, Oxford, U. K.

Holm, D. K., and D. R. Lux (1996), Core complex model proposed for gneiss dome development during collapse of the Paleoproterozoic Penokean orogen, Minnesota, Geology, 24(4), 343-346, doi:10.1130/0091-7613(1996)024<0343: CCMPFG $>2.3 . \mathrm{CO} ; 2$.

Holyoke, C. W., and A. K. Kronenberg (2010), Accurate differential stress measurement using the molten salt cell and solid salt assemblies in the Griggs apparatus with applications to strength, piezometers and rheology, Tectonophysics, 494(1-2), 17-31, doi:10.1016/j.tecto.2010.08.001.

Jefferies, S. P., R. E. Holdsworth, C. A. J. Wibberley, T. Shimamoto, C. J. Spiers, A. R. Niemeijer, and G. E. Lloyd (2006), The nature and importance of phyllonite development in crustal-scale fault cores: An example from the Median Tectonic Line, Japan, J. Struct. Geol., 28(2), 220-235, doi:10.1016/j.jsg.2005.10.008.

Kerrich, R., I. Allison, R. L. Barnett, S. Moss, and J. Starkey (1980), Microstructural and chemical-transformations accompanying deformation of granite in a shear zone at Mieville, Switzerland-With implications for stresscorrosion cracking and superplastic flow, Contrib. Mineral. Petrol., 73(3), 221-242, doi:10.1007/BF00381442. 
Kohlstedt, D. L., B. Evans, and S. J. Mackwell (1995), Strength of the lithosphere - constraints imposed by laboratory experiments, J. Geophys. Res., 100(B9), 17,587-17,602, doi:10.1029/95JB01460.

Kopf, A. (2001), Permeability variation across an active lowangle detachment fault, western Woodlark Basin (ODP Leg 180), and its implication for fault activation, in The Nature and Tectonic Significance of Fault Zone Weakening, edited by R. E. Holdsworth et al., Geol. Soc. Spec. Publ., 186, $23-41$.

Kopf, A., J. H. Behrmann, A. Deyhle, S. Roller, and H. Erlenkeuser (2003), Isotopic evidence (B, C, O) of deep fluid processes in fault rocks from the active Woodlark Basin detachment zone, Earth Planet. Sci. Lett., 208(1-2), 51-68, doi:10.1016/ S0012-821X(03)00016-5.

Little, T. A., S. L. Baldwin, P. G. Fitzgerald, and B. Monteleone (2007), Continental rifting and metamorphic core complex formation ahead of the Woodlark spreading ridge, D'Entrecasteaux Islands, Papua New Guinea, Tectonics, 26, TC1002, doi:10.1029/2005TC001911.

Little, T. A., B. R. Hacker, S. M. Gordon, S. L. Baldwin, P. G. Fitzgerald, S. Ellis, and M. Korchinski (2011), Diapiric exhumation of Earth's youngest (UHP) eclogites in the gneiss domes of the D'Entrecasteaux Islands, Papua New Guinea, Tectonophysics, 510(1-2), 39-68, doi:10.1016/ j.tecto.2011.06.006.

Lus, W. Y., I. McDougall, and H. L. Davies (2004), Age of the metamorphic sole of the Papuan Ultramafic Belt ophiolite, Papua New Guinea, Tectonophysics, 392(1-4), 85-101, doi:10.1016/j.tecto.2004.04.009.

Marone, C., and S. J. D. Cox (1994), Scaling of rock friction constitutive parameters - The effects of surface-roughness and cumulative offset on friction of gabbro, Pure Appl. Geophys., 143(1-3), 359-385, doi:10.1007/BF00874335.

Marquer, D., and M. Burkhard (1992), Fluid circulation, progressive deformation and mass-transfer processes in the upper crust-The example of basement cover relationships in the external crystalline massifs, Switzerland, J. Struct. Geol., 14(8-9), 1047-1057, doi:10.1016/0191-8141(92)90035-U.

McCaig, A. M. (1997), The geochemistry of volatile fluid flow in shear zones, in Deformation-Enhanced Fluid Transport in the Earth's Crust and Mantle, edited by M. B. Holness, pp. 227-266, Chapman and Hall, London.

Miller, J. A., I. S. Buick, I. Cartwright, and A. Barnicoat (2002), Fluid processes during the exhumation of high-P metamorphic belts, Mineral. Mag., 66(1), 93-119, doi:10.1180/ 0026461026610016.

Monteleone, B. D., S. L. Baldwin, T. R. Ireland, and P. G. Fitzgerald (2001), Thermochronologic constraints for the tectonic evolution of the Moresby Seamount, Woodlark Basin, Papua New Guinea, Proc. Ocean Drill. Program Sci. Results, $180,1-35$.

Moore, D. E., and D. A. Lockner (2008), Talc friction in the temperature range $25^{\circ}-400^{\circ} \mathrm{C}$ : Relevance for fault-zone weakening, Tectonophysics, 449(1-4), 120-132, doi:10.1016/ j.tecto.2007.11.039.

Moore, D. E., and M. J. Rymer (2007), Talc-bearing serpentinite and the creeping section of the San Andreas fault, Nature, 448(7155), 795-797, doi:10.1038/nature06064.

Mutter, J. C., C. Z. Mutter, and J. Fang (1996), Analogies to oceanic behaviour in the continental breakup of the western Woodlark basin, Nature, 380(6572), 333-336, doi:10.1038/ $380333 \mathrm{a} 0$.

Niemeijer, A. R., and C. J. Spiers (2006), Velocity dependence of strength and healing behaviour in simulated phyllosilicate- bearing fault gouge, Tectonophysics, 427(1-4), 231-253, doi:10.1016/j.tecto.2006.03.048

O'Hara, K. (1988), Fluid-flow and volume loss during mylonitization-An origin for phyllonite in an overthrust setting, North Carolina, USA, Tectonophysics, 156(1-2), 21-36, doi:10.1016/0040-1951(88)90280-6.

Oliver, N. H. S., I. Cartwright, V. J. Wall, and S. D. Golding (1993), The stable-isotope signature of kilometerscale fracture-dominated metamorphic fluid pathways, Mary Kathleen, Australia, J. Metamorph. Geol., 11(5), 705-720, doi:10.1111/j.1525-1314.1993.tb00182.x.

Ramsay, J. G. (1980), The crack-seal mechanism of rock deformation, Nature, 284, 135-139, doi:10.1038/284135a0.

Reynolds, S. J., and G. S. Lister (1987), Structural aspects of fluid-rock interactions in detachment zones, Geology, 15(4), 362-366, doi:10.1130/0091-7613(1987)15<362:SAOFII $>2.0$. $\mathrm{CO} ; 2$.

Rice, J. R. (1992), Fault stress states, pore pressure distributions, and the weakness of the San Andreas fault, in Fault Mechanics and Transport Properties of Rock, Int. Geophys. Ser., vol. 51, edited by B. Evans and T.-F. Wong, pp. 475-503, Academic, San Diego, Calif., doi:10.1016/S0074-6142(08) 62835-1.

Rolland, Y., S. Cox, A. M. Boullier, G. Pennacchioni, and N. Mancktelow (2003), Rare earth and trace element mobility in mid-crustal shear zones: Insights from the Mont Blanc Massif (western Alps), Earth Planet. Sci. Lett., 214(1-2), 203-219, doi:10.1016/S0012-821X(03)00372-8.

Rutter, E. H., R. H. Maddock, S. H. Hall, and S. H. White (1986), Comparative microstructures of natural and experimentally produced clay-bearing fault gouges, Pure Appl. Geophys., 124, 3-30, doi:10.1007/BF00875717.

Schaltegger, U., L. Desmurs, G. Manatschal, O. Muntener, M. Meier, M. Frank, and D. Bernoulli (2002), The transition from rifting to sea-floor spreading within a magma-poor rifted margin: Field and isotopic constraints, Terra Nova, 14(3), 156-162, doi:10.1046/j.1365-3121.2002.00406.x.

Scholz, C. H. (1998), Earthquakes and friction laws, Nature, 391(6662), 37-42, doi:10.1038/34097.

Selverstone, J., G. Morteani, and J. M. Staude (1991), Fluid channeling during ductile shearing-Transformation of granodiorite into aluminous schist in the Tauern Window, eastern Alps, J. Metamorph. Geol., 9(4), 419-431, doi:10.1111/j.1525-1314.1991.tb00536.x.

Shimamoto, T., and J. M. Logan (1981), Effects of simulated clay gouges on the sliding behavior of Tennessee sandstone, Tectonophysics, 75, 243-255, doi:10.1016/0040-1951(81) 90276-6.

Sinha, A. K., D. A. Hewitt, and J. D. Rimstidt (1986), Fluid interaction and element mobility in the development of ultramylonites, Geology, 14(10), 883-886, doi:10.1130/00917613(1986)14<883:FIAEMI >2.0.CO;2.

Smith, D. K., J. R. Cann, and J. Escartin (2006), Widespread active detachment faulting and core complex formation near $13^{\circ} \mathrm{N}$ on the Mid-Atlantic Ridge, Nature, 442(7101), 440-443, doi:10.1038/nature04950.

Speckbacher, R., J. H. Behrmann, T. J. Nagel, M. Stipp, and C. W. Devey (2011), Splitting a continent: Insights from submarine high-resolution mapping of the Moresby Seamount detachment, offshore Papua New Guinea, Geology, 39(7), 651-654, doi:10.1130/G31931.1.

Stern, R. J. (2004), Subduction initiation: Spontaneous and induced, Earth Planet. Sci. Lett., 226, 275-292.

Steyrer, H. P., and R. Sturm (2002), Stability of zircon in a low-grade ultramylonite and its utility for chemical mass 
balancing: The shear zone at Mieville, Switzerland, Chem. Geol., 187(1-2), 1-19, doi:10.1016/S0009-2541(02)00010-4.

Stipp, M., and J. Tullis (2003), The recrystallized grain size piezometer for quartz, Geophys. Res. Lett., 30(21), 2088, doi:10.1029/2003GL018444.

Stipp, M., H. Stünitz, R. Heilbronner, and S. M. Schmid (2002), The eastern Tonale fault zone: A 'natural laboratory' for crystal plastic deformation of quartz over a temperature range from 250 to $700^{\circ}$ C, J. Struct. Geol., 24(12), 1861-1884, doi:10.1016/S0191-8141(02)00035-4.

Stipp, M., J. Tullis, and H. Behrens (2006), Effect of water on the dislocation creep microstructure and flow stress of quartz and implications for the recrystallized grain size piezometer, J. Geophys. Res., 111, B04201, doi:10.1029/2005JB003852.

Streit, J. E., and S. F. Cox (1998), Fluid infiltration and volume change during mid-crustal mylonitization of Proterozoic granite, King Island, Tasmania, J. Metamorph. Geol., 16(2), 197-212, doi:10.1111/j.1525-1314.1998.00129.x.

Tani, K., D. J. Dunkley, and Y. Ohara (2011), Termination of backarc spreading: Zircon dating of a giant oceanic core complex, Geology, 39(1), 47-50, doi:10.1130/G31322.1.

Taylor, B., and P. Huchon (2002), Active continental extension in the western Woodlark Basin: A synthesis of Leg 180 results, Proc. Ocean Drill. Program Sci. Results, 180, 36 pp.

Taylor, B., A. Goodliffe, F. Martinez, and R. Hey (1995), Continental rifting and initial sea-floor spreading in the Woodlark Basin, Nature, 374(6522), 534-537, doi:10.1038/374534a0.

Taylor, B., P. Huchon, and A. Klaus (1999), Proceedings of the Ocean Drilling Program, Initial Reports, vol. 180, 75 pp., Ocean Drill. Program, College Station, Tex.

Tucholke, B. E., J. Lin, and M. C. Kleinrock (1998), Megamullions and mullion structure defining oceanic metamorphic core complexes on the mid-Atlantic ridge, J. Geophys. Res., 103(B5), 9857-9866, doi:10.1029/98JB00167.

Van Wijk, J. W., and D. K. Blackman (2005), Dynamics of continental rift propagation: The end-member modes, Earth
Planet. Sci. Lett., 229(3-4), 247-258, doi:10.1016/j.epsl.2004. 10.039 .

Vrolijk, P., and B. A. Van der Pluijm (1999), Clay gouge, J. Struct. Geol., 21(8-9), 1039-1048, doi:10.1016/S01918141(99)00103-0.

Wallace, L. M., C. Stevens, E. Silver, R. McCaffrey, W. Loratung, S. Hasiata, R. Stanaway, R. Curley, R. Rosa, and J. Taugaloidi (2004), GPS and seismological constraints on active tectonics and arc-continent collision in Papua New Guinea: Implications for mechanics of microplate rotations, J. Geophys. Res., 109, B05404, doi:10.1029/2003JB002481.

Weissel, J. K., and A. B. Watts (1979), Tectonic evolution of the Coral Sea Basin, J. Geophys. Res., 84(B9), 4572-4582.

Weissel, J. K., B. Taylor, and G. D. Karner (1982), The opening of the Woodlark Basin, subduction of the Woodlark Spreading System, and the evolution of northern Melanesia since Mid-Pliocene time, Tectonophysics, 87(1-4), 253-277, doi:10.1016/0040-1951(82)90229-3.

Wickham, S. M., M. T. Peters, H. C. Fricke, and J. R. Oneil (1993), Identification of magmatic and meteoric fluid sources and upward-moving and downward-moving infiltration fronts in a metamorphic core complex, Geology, 21(1), 81-84, doi:10.1130/0091-7613(1993)021<0081:IOMAMF>2.3.CO;2.

Zartman, R. E., and S. M. Haines (1988), The plumbotectonic model for $\mathrm{Pb}$ isotopic systematics among major terrestrial reservoirs-A case for bi-directional transport, Geochim. Cosmochim. Acta, 52(6), 1327-1339, doi:10.1016/00167037(88)90204-9.

Zindler, A., and S. Hart (1986), Chemical geodynamics, Annu. Rev. Earth Planet. Sci., 14, 493-571, doi:10.1146/annurev. ea.14.050186.002425.

Zoback, M. D. (2000), Earth science - Strength of the San Andreas, Nature, 405(6782), 31-32, doi:10.1038/35011181. 